Discussion Paper No. 939

\title{
KNOWLEDGE DIFFUSION AND INDUSTRY GROWTH: \\ THE CASE OF JAPAN'S EARLY COTTON SPINNING INDUSTRY
}

Serguey Braguinsky

June 2015

The Institute of Social and Economic Research Osaka University

6-1 Mihogaoka, Ibaraki, Osaka 567-0047, Japan 


\author{
Knowledge Diffusion and Industry Growth: \\ The Case of Japan's Early Cotton Spinning Industry \\ Serguey Braguinsky \\ Department of Social and Decision Sciences, \\ Carnegie Mellon University, and NBER ${ }^{1}$
}

\begin{abstract}
The diffusion of technological knowledge is key to industry growth. But not all knowledge is created equal. I use a nanoeconomic approach to examine knowledge-diffusion based growth in the Meiji-era Japanese cotton spinning industry, which enjoyed remarkable success after a decade of initial failure. By tracing sources of technological knowledge to individual engineers, I find that successful technology diffusion required the right kind of human capital embodying and transmitting knowledge, and a competitive environment that rewarded talent while weeding out incompetence.

JEL classification numbers: O33, O14
\end{abstract}

This draft: May 2015

\footnotetext{
${ }^{1} 5000$ Forbes Avenue, Pittsburgh, PA, 15213. E-mail: sbrag@andrew.cmu.edu Forthcoming in Industrial and Corporate Change. Part of the work on this paper was done while I was a Visiting Research Scholar at Osaka University Institute for Social and Economic Research, whose hospitality is greatly appreciated. I am eternally grateful to my late colleague Steven Klepper for inspiration, encouragement, and advice at the early stages of this project. I also thank Rajshree Agarwal, David A. Hounshell, Atsushi Ohyama, an anonymous referee, and the participants at the Klepper Memorial Conference at Carnegie Mellon University in October 2014 for helpful comments and suggestions. All remaining errors of fact or judgment are mine and mine only.
} 


\section{Introduction}

The rate at which new techniques are adopted and incorporated into the productive process has long been recognized as "one of the central questions of economic growth" (Rosenberg, 1972). In the neoclassical growth theory operating with the notion of a representative firm, technology is viewed as "disembodied," and its diffusion as happening through an "externality" (e.g., Lucas, 1988). The same is essentially true of theories of endogenous growth, where new technologies are generated through targeted investments but still conducted by firms that are ex ante identical and utilizing accumulated past knowledge available to them as a disembodied externality (e.g., Romer, 1990; Grossman and Helpman, 1991).

In the seminal paper in the literature on industry evolution (Gort and Klepper, 1982), Michael Gort and Steven Klepper proposed a different approach, one that was based on "Schumpeterian dynamics, and the explicit recognition of heterogeneity among firms" (Agarwal and Braguinsky, forthcoming). The initial focus of this approach, however, was not so much on the process of knowledge diffusion as on industry-specific knowledge accumulation by incumbent firms. The basic idea is formulated in Gort and Klepper (1982: 632-33) where they hypothesize that accumulated non-transferable firm-specific knowledge becomes progressively more important compared to transferable individually appropriable knowledge as the industry matures. In the formal model offered by Klepper (1996), incumbents absorb innovations by new entrants automatically and almost instantaneously, and the specific channels through which such innovations and their diffusion occur are not explicitly considered (see also Jovanovic and MacDonald, 1994, for a similar approach to diffusion).

Compared to this, there has been less attention in the literature dedicated to generation and diffusion of knowledge, especially at early stages of the industry life-cycle (notable exceptions include Agarwal and Gort, 2001; Agarwal and Bayus, 2002; Moeen and Agarwal, 2015; among others). This is particularly true with regard to nanofactors that ensure generation and diffusion not of any but of the right kind of knowledge. Klepper himself has certainly recognized the importance of this factor, as witnessed by the fact that he would trace the success of whole industries to one exceptionally gifted (and oftentimes, as he argued, also hard-to-work-with) individual (Ransom Olds in the U.S. auto industry, William Shockley in Silicon Valley - see Klepper, 2016, especially Chapter 3). This paper aims at contributing to this aspect of industry 
evolution literature by employing nanoeconomic approach and historical methodology (Klepper, 2011; see also Braguinsky and Hounshell, 2015b).

One problem that presents itself when examining instances of knowledge diffusion in early stages of the industry lifecycle is that industry evolution research has dealt almost exclusively with success stories (a notable exception is Lerner, 2009). While this is understandable, it leads to a problem well known in econometrics as "sample selection bias." In other words, the analysis of success cases of knowledge diffusion-based industry growth lacks a control group against which these cases can be meaningfully compared. The problem is even more severe at the firm level. Tracing firms' backgrounds requires painstaking effort and often proves impossible outside of already known successful clusters, such as Silicon Valley (Klepper, 2010). The data on firm performance and even survival are often also available to a researcher only on a subset of the total firm population of the industry, namely, those of them that had a chance to grow large enough and thus were relatively successful. But firm-level success is not always attributable solely to superior technological knowledge; hence, examining the process of knowledge creation and diffusion on the subsample of successful firms only may result in hindsight bias, where things that happened are interpreted as being much more pre-determined or inevitable than they actually were (Fischoff, 1980). One way of avoiding such bias is to keep full records of a nascent industry right from the outset. While such cases in the past seem to be extremely rare, they should become more available as more effort is dedicated to such fact-recording about new emerging industries.

While in the ideal world a researcher would like to have a "randomized" experiment to tease out the factors that distinguish knowledge diffusion-based success and failure, such an experiment is, of course, not feasible. Without it, we need to study cases where industries initially struggled to find their ways of diffusing the best kind of knowledge and start growing and then found a way to succeed through what Hausmann and Rodrik (2003) aptly called the "self-discovery" process. The case of the Meiji-era Japanese cotton spinning industry presents a unique opportunity in this regard. Its spectacular success, based on "super-fast" (Saxonhouse, 1974) diffusion of the best technological and managerial practices, has been studied in the English-language literature for at least forty years. ${ }^{i}$ Less well known is the fact that this success came very closely on the heels of an earlier failure of what at least on the surface looked like a very similar attempt. Most actors (firms and individuals) also overlapped and kept interacting with each other during both phases, making it possible to compare directly the factors that led to success and those that led to failure. 
I employ the "nanoeconomic" database built in collaboration with Japanese colleagues, Atsushi Ohyama, and Tetsuji Okazaki, to examine both early struggles and eventual success of this industry, and by doing so, to advance our understanding of what it takes to generate and diffuse the right kind of knowledge in a nascent industry. Another contribution of this paper is that it (together with other related papers mentioned below) fundamentally recasts our understanding of the emergence of the first, globally competitive industrial sector in a non-Western country. ${ }^{\text {.i }}$ The historical circumstances surrounding this development, described in the next section, made the story even more amazing.

Three other recent papers draw on parts of the same database. In Braguinsky, Ohyama, Okazaki, and Syverson (2015) we examine the role played by mergers and acquisitions in improving plant-level productivity and profitability during the industry consolidation phase in the first two decades of the $20^{\text {th }}$ century. In Braguinsky and Hounshell (2015b) coevolution of the industry and the firms comprising it is examined from strategic management point of view through several stages of industry evolution. The paper most closely related to this one is Braguinsky and Hounshell (2015a), which retells the "tale" in Gary Saxonhouse's (1974) pioneering article on cooperative technology diffusion in the Japanese cotton spinning industry, clarifying the role played by market competition as opposed to the industry association (Boren). The current paper advances both the data and the analysis in Braguinsky and Hounshell (2015a). Specifically, I examine the impact of different sources of technological knowledge and diffusion networks on individual firms' technological choices and outcomes. These sources are traced to individual engineers and technologists (together with their educational background and experience) at the center of each network. As a result of this more detailed "nanoanalysis," I am able to characterize more fully than was possible before both the failure and the success parts of the story and to link the factors that led to different outcomes in seemingly uniform environment to links between firms and engineers they hired.

In the next section I summarize extant research in the form of several "stylized facts," and I then describe two unresolved research questions that emerge from those and which this paper tries to shed light on. Section III contains a brief description of the evolution of the Meiji-era cotton spinning industry in Japan and my data sources. In Section IV I present an in-depth, "nanoeconomic" analysis of the process of knowledge accumulation and diffusion in this industry from its early failure to the later success. By doing so I address the research questions stated in 
Section II by identifying the most important factors that made the transition from failed knowledge diffusion to a successful one possible. Such an examination is greatly facilitated by incredibly rich archival materials on the industry, which allow me to follow the universe of all firms and production facilities operating in the industry virtually from its inception and directly observe their technological choices as well as interfirm flows of knowledge through founders' networks and worker training. Section V concludes.

\section{II.1 Some "stylized facts" from extant studies}

The first "stylized fact" that can be distilled from past research is that the initial impetus to industry success usually comes from experimentation by a few standout entrepreneurs (firms) or sometimes even from one single such firm. In the U.S. auto industry it was Ransom Olds and Olds Motor Works (Klepper, 2010), in the TV receivers industry it was Vladimir Zworykin (RCA) and Philo Farnsworth (Klepper and Simons, 2000), in the U.S. semiconductor industry it was William Shockley and Fairchild Semiconductor (Klepper, 2009), and in the personal computer industry it was Steve Jobs and Apple (e.g., Isaacson, 2011). The evidence is not limited to the U.S.; in fact, multiple similar cases have been identified across countries and historical epochs: such as Eiichi Shibusawa and Osaka Spinning Company in Japan's cotton spinning industry circa late $19^{\text {th }}$ century (Braguinsky and Hounshell, 2015b), Thonet Brothers and Kohn Brothers in the Austrian bentwood furniture industry around the same time (Kiriazidou and Pesendorfer, 1999), Salmones Antartica in the late twentieth century Chilean salmon industry (Petrobielli and Rabelotti, 2004), and Desh Garments in recent Bangladeshi garment industry (Mostafa and Klepper, 2011).

The second "stylized fact" is that technological and managerial practices developed through experimentation by the best firms diffuse not as a "disembodied externality" but through movement of individuals possessing relevant knowledge and experience. Hounshell and Smith (1988: Ch. 3) demonstrate on the example of the post-World War I U.S. dyestuff industry that even full access to disembodied knowledge in the form of patent descriptions was not enough to close the gap with the German industry until Du Pont (in blatant violation of international legal arrangements) head-hunted top German chemical engineers. Klepper's "nanoeconomic" studies of several U.S. industries noted above also clearly demonstrate that the diffusion of best practices and firm outcomes can be unambiguously traced to such "embodied" transfer of knowledge and experience through the human capital of firm founders.iii 
The third "stylized fact" is that many cases of spectacular growth through knowledge diffusion tend to happen in strongly competitive and globally connected environments. In the above-mentioned cases of the Japanese cotton spinning industry, the Austrian bentwood furniture industry, the Chilean salmon industry, and the Bangladeshi garment industry the environment was that of a nascent industry establishing its position in a globally competitive export market. Fierce competition has been and continues to be the hallmark of Silicon Valley, and early U.S. auto and tire industries present similar pictures. Summarizing a large number of studies of industrial clusters world-wide, Morosini (2004, p. 316) observes that "firms in industrial clusters that present a high degree of knowledge integration and compete globally, innovate more, present stronger growth patterns, adapt to changing environmental conditions more rapidly and have a more sustainable economic performance than firms in less integrated clusters that tend to compete within strictly local geographic boundaries."

The fourth "stylized fact" is that access to finance plays an important role in the process of emergence of new industries, which face a rapidly changing environment with a lot of uncertainty and risks. While self-financing in the long run can undo most of the damage caused by capital misallocation in situations where productivity shocks are persistent, in environments characterized by transient productivity shocks, the ability of entrepreneurs to self-finance is considerably hampered (Moll, 2014). The latter is exactly what an emerging industry is likely to face and therefore nascent industries normally have to rely on either the government providing the initial market for their products or on venture capital financing (Goldfarb et al., 2012; Klepper, 2016).

\section{II.2 Questions for further research}

Two questions that require further research emanate from the above "stylized facts." The first such question is what exactly the factors are that make possible knowledge diffusion of the right kind from the best firms to the rest of the industry. Existing literature, as discussed immediately below, points to several potential factors but it is not quite clear how they interact with each other. The second, and closely related, question is why spectacular success stories of industry growth through knowledge diffusion are still so rare.

With respect to the first question above, Klepper himself emphasized "the role established firms, particularly the leading ones, played in involuntarily training the next round of entrepreneurs that propelled their industries forward" (Braguinsky and Klepper, 2009: 29). ${ }^{\text {iv }}$ The evidence from 
employee startups in the automobile industry in Detroit, the semiconductor industry in Silicon Valley, the U.S. laser industry, and others show that they were indeed motivated mainly by the unwillingness of their employers to aggressively pursue promising new ideas (see also Agarwal, Echambadi, Franco, and Sarkar, 2004). Klepper and Thompson (2010) present a theory based on disagreements stemming from differentiated ability that would account for this phenomenon.

There is another strand in the literature, however, that emphasizes knowledge diffusion through what looks like a deliberate decision by industry-leading firms. For example, when asked about the strategy adopted by Bell Laboratories of not just licensing their innovations but also telling the licensees all that they knew, the firm's vice president for electronic components development reportedly said: "We realized that if this thing was as big as we thought, we couldn't keep it to ourselves and we couldn't make all the technical contributions. It was to our interest to spread it around. If you cast your bread on the water, sometimes it comes back angel food cake" (cited in Tilton, 1971: 75-76). In the 1950s, Bell Laboratories also "emerged as the major source of semiconductor scientists and engineers, and has since served as the principal training ground for numerous semiconductor specialists.” (ibid., p. 81). ${ }^{\vee}$ In Japan’s Meiji-era cotton spinning industry incumbent firms proactively helped new entrants by offering training to their employees and generally kept almost all the information about best technological and managerial practices open (Saxonhouse, 1974). Similarly, in Austrian bentwood furniture industry "an important feature ... was the free flow of information ... New technical achievements and product designs were exploited not only by the firm that invented them, but also by competitors" (Kiriazidou and Pesendorfer, 1999: 157). Instances of "collective search" have also been uncovered in a large number of other important historical cases, from the Cleveland Steel District (Allen, 1983) and Cornish steam engine (Nuvolari, 2004) in England at the dawn of the industrial revolution, to flat panel display industry (Spencer, 2003), to early personal computer industry (Meyer, 2003).

Regarding the second question, the lack of trying is certainly not the reason. On the contrary, once successful cases became widely known, they inevitably sparked attempts to imitate them. One early known example comes from British Dyes (Limited), a company established with a specific task to emulate the German system of innovation in the dyestuff industry. The project went nowhere because it "has made use of entirely unskilled agents - and, as was to be expected, the failure has been complete" (Science, Vol. 68, No. 1239, 1918, p. 314). More recent attempts in various countries to create high-technology clusters modeled after Silicon Valley-from the 
Brittany province in France in the 1990s, to "BioValley" in Malaysia, to Australia's BITS (Building on Information Technology Strengths) incubator program-have all also failed due to either bad incentives or lack of competence or both (Lerner, 2009).

Globally connected, competitive environment ("stylized fact" number 3 above) appears to be the key in answering both above questions. With regard to employee startups as a way of promoting innovation and diffusion, these are clearly fostered by eliminating non-competes and other anti-competitive practices as well as providing venture capital financing to new startups. Numerous studies show that contrary to the views pushed by incumbent firms, allowing employees to move freely and start their own firms increases both the rates of innovation and diffusion (see, e.g., Gilson, 1999; Marx, Strumsky, and Fleming, 2009).

Less obvious but nevertheless true is that innovation and diffusion through collaboration and knowledge sharing also tend to thrive in a competitive environment. The description of the Homebrew Computer Club from which Apple emerged in Isaacson (2011) leaves no doubt that young "geeks" in that club were fiercely competitive even as they shared ideas with each other. As detailed below, fierce competition that did not allow the survival of inefficient firms was also a salient feature of the knowledge-sharing based success in Japanese cotton spinning. From a theory vantage point, the initial limited size of the industry (compared to the size of the potential market) makes it possible for knowledge sharing to be privately optimal under competitive markets (see Braguinsky, Gabdrakhmanov, and Ohyama, 2007; Braguinsky and Rose, 2009).

Competitive environment, in confluence with access to initial financing ("stylized fact" number 4 above), also likely holds the key to answering the second question posed above, as to why success cases are so rare. There is a natural tendency to use public sources to secure initial financing and/or provide the initial market to a new industry with uncertain technology and no established best practices. Cases where this happened without interfering with global connectedness and the principle of competition (e.g., semiconductor industry in Taiwan — see Mathews, 1997-or Yozma program in Israel-see Avnimelech and Teubal, 2004) were successful but also rare. As a general rule, maintaining competition in the face of challenges of a new, especially high-tech industry has proven to be elusive, not least because of some conventional wisdoms about "infant industry" and intellectual monopoly protection still pervasive among policy-makers (Boldin and Levine, 2010). It is especially important to emphasize in this context that competition and global connectedness not only help prevent capture by special interests, but 
also allocate scarce resources to areas where there is already a basis of required knowledge and competence. ${ }^{\mathrm{vi}}$ The examination of the Meiji-era cotton spinning industry in Japan beginning in the next section will present some additional insights into these issues.

\section{Meiji-era cotton spinning industry in Japan: overview and data}

Japan opened up to foreign trade in the 1860s after 250 years of autarky. This opening up of the country was so "sudden and complete" that it allowed to treat this case as a "natural experiment" to explore the empirical validity of the comparative advantage theory (Bernhofen and Brown, 2004). In line with that theory, Japan's pre-modern manufacturing production was wiped out, with cotton yarn experiencing the combination of the largest fall in relative price from autarky to the free trade regime and the highest negative net exports (ibid., Figure 4).

Needless to say, mechanized cotton spinning was the industry that started the industrial revolution in England, and it was the industry that each country that embarked on the path of industrialization during the nineteenth century tried to establish first. In 1878, the Meiji government, deeply concerned about the growing amount of specie flowing out for imported textile goods, started promoting the cotton spinning industry by constructing and operating "model mills" and by purchasing British spinning machinery and reselling it to private entrepreneurs it recruited at subsidized prices and with easy loan terms. In 1882, it created the "All Japan Cotton Spinners Association" (known by its Japanese acronym "Boren") with the specific aim of facilitating the transfer of best-practice spinning technology to and its diffusion within Japan. Boren immediately began collecting and disseminating (initially through the government-issued "Official Gazette" and later through its monthly bulletin, "Geppo") detailed firm-level data on inputs (machine spindles in operation, number of male and female operatives, type of engines operating the plant and its horse power, the amount of cotton yarn consumed in production, and separately the amount of recovered waste cotton, etc.) and output (the amount of cotton yarn produced, its main count, vii the amount of waste yarn), as well as firm-specific output prices and operatives' wages. These monthly tables, preserved in archival records until our time, serve as one of the sources of the data used in this study. viii

Early studies tended to credit these efforts with helping the industry to overcome the initial difficulties of industrialization (e,g., Smith, 1955; Landes, 1965). In reality, however, the 
government-led effort by itself did not accomplish this. Figure 1 presents the earliest available data on domestic output, imports and exports of cotton yarn in physical units (thousands of pounds).

[Figure 1 about here]

As can be seen from Figure 1, domestic output remains negligible until 1885, and while it starts increasing beginning in 1886, it hardly puts a dent in imports until the very end of the 1880s. More importantly, as firm-level data presented below show, the upward trend in domestic output starting from 1886 came from knowledge sources that had nothing to do with government efforts to promote the industry.

In 1886 the government withdrew both its support and intervention in the industry. As documented by government's own historians writing some fourteen years later (Enkakukiji, 1900, Chapter 1), the main reason was poor performance of government-promoted mills contrasted to the success of the first large private company to emerge in the industry by that time (Osaka Spinning Company, more on this below). This abrupt policy change laid the foundation for the period of coexistence between former government-aided mills and new independent private entrants, allowing me to compare the process of technology and knowledge diffusion between these two categories operating in the same period and under the same market environment.

Figure 2 shows the dynamics of domestic output, imports and exports of cotton yarn in Japan over the 1890s. As can be seen already from Figure 1, the industry took off in the very last few years of the 1880s and domestic output exceeded imports for the first time in 1890. Figure 2 shows that output continued to grow at a very fast rate throughout the subsequent 10 years, while imports quickly became an afterthought and instead exports burgeoned in the second half of the 1890s. After consolidation in the early 1900 s, the industry continued to grow rapidly and by the 1920s became one of the largest in the world, a major player on the global cotton yarn export market. Almost all of this growth came from new private mills. Boren was reorganized into the association of independent producers in 1888 but its functions remained essentially the same, and it continued to operate as the institutional arrangement for knowledge diffusion and technology dissemination albeit under new leadership. This, along with other evidence from the history of the industry (see Kinugawa, 1964), shows that there was little change in the way knowledge diffusion was organized at the industry level between the $1880 \mathrm{~s}$ and the $1890 \mathrm{~s}$.

In the next section I conduct an in-depth, "nanoeconomic" investigation of the process of knowledge diffusion in Japan's cotton spinning industry during the first two decades of its 
existence (the 1880s and the 1890s). I compare technology choices adopted by firms that relied on government-aided knowledge diffusion mechanism to technology choices adopted by independent private entrants and their sources. These differences can be linked directly to very different outcomes observed in Figures 1 and 2.

As mentioned, the data on input and output choices come from the monthly data collected by Boren. These are supplemented by the data on dates of founding (defined as the date when the registration of the firm was granted by the prefectural authority in charge of business registry) and dates of the actual start of operation for each firm that operated in the industry at some point from the early 1880s-end of the 1890s from "Enkakukiji," the unpublished but highly influential industry history written by the Japanese government sources at the beginning of the twentieth century. Enkakukiji also contains the data on the number and type (ring or mule) of spindles installed and decommissioned by each firm in each year. The information on the backgrounds of founders, top managers and technicians comes from the seven-volume history of the industry written in the 1930s by Taiichi Kinugawa (Kinugawa, 1964), which contains separate chapters dedicated to each firm. Whenever possible, I verified this information and supplemented it using firms' shareholder reports and firm-specific information published in Boren's monthly bulletins ("Geppo"). Educational background of engineers was also verified through the lists of graduates of the Imperial College of Engineering (later Imperial University Department of Engineering). Technology data on the characteristics of machinery ordered by different firms in the 1880 s and 1890s used below come from the file compiled by Gary Saxonhouse and Patrick McGuire and archived on the ICPSR web site (Wright, 2011). Braguinsky and Hounshell (2015a) describe these data sources in more detail.

\section{IV.1. Knowledge diffusion and technology choices under government sponsorship}

Even though first attempts to establish mechanized cotton spinning industry in Japan date back to the $1860 \mathrm{~s}$, the process started in earnest in the late 1870s. As mentioned, the Meiji government, promoted the industry by creating "model mills" and subsidizing about a dozen more by purchasing British spinning machinery and reselling it at subsidized prices and with easy loan terms. Despite the obvious failure of those efforts in terms of increasing domestic production and replacing imports (see Figure 1 above), it is still possible, at least in theory, that those efforts "produced important demonstration effects and trained many skilled artisans and managers" 
(Rodrik, 2014: 83), and thus contributed to knowledge diffusion that sparked subsequent spectacular industry growth. It is thus important to examine the available "nano" evidence about knowledge diffusion in early years of the industry.

Government-led knowledge dissemination conducted through early Boren was supervised by its technology "guru," Masatatsu Ishikawa (1825-1895). Ishikawa's biography is described in detail in Kinugawa (1964, I: Ch. 3). According to it, he was born in an educator's family but was not a "samurai" (nobleman) by birth. He left home at the age of twenty to study in Nagasaki, the port city in the south of Japan, which was the only one open for trade and cultural exchange with the West at the time. The only nation to which Nagasaki was open at the time was the Dutch, so Ishikawa learned the Dutch language. It appears that he had never learned to read or understand English, so when he later needed to understand a technical document about cotton spinning written in English, he had to send it to Nagasaki to have it translated first. The translation endeavor alone took a whole year (Kinugawa, 1964, I: 87).

Ishikawa had no training as an engineer, let alone as an engineer in cotton spinning (whatever studies in engineering he completed while at Nagasaki appear to have been on military artillery). Nevertheless, in what was still the pre-Meiji Japan he landed a job with Nariakira Shimazu, the Lord of Satsuma (modern day's Kagoshima prefecture on the southern tip of the southernmost island of Kyushu) who awarded him the rank of a "samurai" and made him his personal advisor.

Using its remote location to evade the rules forbidding contacts with foreign powers, Satsuma principality was the first in pre-Meiji Japan to start exploring ways to modernize its economic and military capacity. Pre-empting the central government's efforts, Nariakira Shimazu sponsored and oversaw the construction of the first hub of experimental western-style factories in Japan ("shuseikan"), right by his seaside summer residence. The factories included the first reverberatory furnace in Japan used to cast Satsuma's own iron cannons and a small shipbuilding yard, but they were all destroyed by the British artillery fire during the two-day Anglo-Satsuma War in August 1863. Satsuma-fired cannons, however, did inflict some serious damage on the British fleet as well. The two sides quickly made peace. In 1865 Satsuma sent a mission to England, one of the aims of which was to request assistance from Platt Brothers of Oldham in adding a modern cotton textile factory to its rebuilt industrial hub. ${ }^{\text {ix }}$ Thus, the first mechanized cotton spinning and weaving mill in Japan started operating in Kagoshima in 1867. 
It is not clear if Ishikawa directly oversaw the operations of this first mill, but archival documents show that he was put in charge of the next one set up the next year by Satsuma on the land it owned in the city of Sakai, near Osaka, the heart of Japanese industry and commerce at the time. In 1872 the new Meiji government bought the mill from Satsuma and converted it into its first "model" mill tasked with spreading mechanized cotton spinning. Ishikawa continued to run the mill, and became employed by the government. Subsequently, the government ordered him to set up the Aichi National Mill, a brand-new plant that was designed to become the flagship of the government-promoted cotton-spinning industry (it started operating in 1881). Seventeen more mills either directly owned by the government (including prefectural governments) or subsidized by the government started operating between 1882-1885. Ten of those were designed, assembled and started operating under supervision from Ishikawa or his close associates also employed by the government. Seven other mills, even though they also received financial support from the government, were not guided by Ishikawa. Instead, they relied on engineers they themselves hired and/or on advice obtained from another pioneering firm, founded in Tokyo in 1865 (that is, also prior to Meiji restoration) by a private entrepreneur Manbei Kashima (Okamoto, 1995).

To examine whether technology diffusion through government-appointed technology advisor (Ishikawa or his subordinates, hereafter "Ishikawa" for short) helped the mills I estimate a regression where productivity metrics of mills (measured in physical units) are regressed on the dummy equal to 1 if the firm was directed by Ishikawa and 0 otherwise, while controlling for yearmonth fixed-effects. The sample is from 1883 (when the first data become available) to 1886, which is the last year under government promotion policies and it includes all government-aided mills (but excludes the two mills not aided by the government, notably Osaka Spinning Company-more on this below). The estimation equation is

$$
y_{i}=\alpha+\beta D_{i}+\mu_{t}+\epsilon_{i t},
$$

where $y_{i}$ is the outcome variable, $D_{i}$ is the dummy equal to 1 if the firm was advised by Ishikawa and 0 otherwise, $\mu_{t}$ is the year-month fixed effect, and $\epsilon_{i t}$ is the firm-specific random error term. I use logged labor productivity (monthly output in weight units, divided by the total number of worker-days employed) and logged capital productivity (monthly output in weight units, divided by the total number of spindle-days in operation) as outcome variables. I also estimate the production function with logged output as a function of logged capital input, logged labor input, 
and year-month fixed effects and use the residuals from this estimation as a measure of total factor productivity, which is then used as the outcome variable in regression (1). ${ }^{\mathrm{x}}$

Average capital productivity of the mills guided by Ishikawa is estimated to be about 25 percent $(\exp (-0.288)-1)$ below that of firms that were not guided by him (statistically highly significant); average labor productivity is lower by about 10 percent (statistically significant at the 5 percent level). Total factor productivity of Ishikawa-guided mills is about 16 percent lower on average than that of mills he did not work with.

Productivity differentials in Table 1 show that mills that relied directly on governmentpromoted technological knowledge had worse, not better outcomes compared to other mills. In principle, those outcomes could be due to some other factors (such as bad luck), not necessarily inferior technologies themselves. I therefore use the detailed nature of the available data to compare directly technology-related choices made by Ishikawa-guided mills and other mills to see if there are systematical differences between the two.

Table 2 presents the differences in means of mill size (number of spindles installed), power sources (water engine versus steam engine), capital to labor ratios (defined as the number of spindles in operation, divided by the number of operative employed in each month), and the ratios of female to male factory operatives (blue-collar workers). The sizes of both types of mills are very similar (just barely above 2,000 spindles) and reflect the overall government policy of subsidizing 2,000-spindle mills across the country (Braguinsky and Hounshell, 2015a). But other choices are starkly different. Especially water engines were the main source of power in almost 70 percent of observations on mills run by Ishikawa but in less than 25 percent of observations on mills not run by him. Relying on water engines severely limited the mills' choices of where to locate, creating logistic problems as a result. Given the nature of Japanese climate it also subjected them to repeated seasonal shortages of power. Ishikawa's well-documented insistence on hydro energy as the main source of power is even more baffling in view of the fact that both early Satsuma mills he had experience with were powered by steam engines. Table 2 also shows that mills directed by Ishikawa were significantly more capital-intensive, and tended to employ more female operatives relative to male operatives than other mills. As shown below, best practices subsequently established in the industry involved labor-intensive production technology, coupled with a high share of female operatives in the workforce. Ishikawa's choice of running capital- 
intensive mills while relying at the same time extensively on female labor thus pushed the industry in the wrong direction.

Another wrong technological choice made by Ishikawa, which affected all governmentpromoted firms, not just those that he supervised directly, was the choice of William Higgins and Sons as the machine supplier (recall that the government purchased machines from England and then sold it to all subsidized firms). Drafting rollers in those machines were designed for mediumstapled U.S. cotton and were particularly unfit for short-stapled Japanese cotton which mills used as inputs (Tamagawa, 1995). Again, the reason why Ishikawa recommended Higgins and Sons is not clear - as mentioned, Satsuma had approached Platt Brothers for machines and engineers for its first mill. Platt Brothers later became the main supplier for new private entrants into the industry, but not before Osaka Spinning Company re-established contact with it.

It is thus apparent that all that the knowledge diffusion through the government-run industry association could accomplish was to hammer in all the wrong choices. As summarized in a remarkably honest speech by Kokufuku Kan, the manager in charge of one of the governmentsubsidized mills, given to Boren in 1885,

"Lacking capital and educated knowledge, and guided by reckless small-town quasipatriotic feeling only because we felt bad about spending 7 million yen per year on imported cotton yarn, we unbecomingly planned a great enterprise, letting government officials dictate things, not gauging our own ability, and almost completely failed to deliver any progress up until this very day." (cited in Nawa, 1937, p. 98)

To sum up, contrary to some conventional wisdoms, the knowledge transmitted through government-owned "model" mills and government-subsidized mills contributed almost nothing to the subsequent "winning combination" of technology and management that propelled the industry to its success starting in the late 1880 s. They did not serve as the training facilities for the right kind of managers and engineers either. The right kind of knowledge and the right kind of human capital emerged from a totally different source and proliferated by means of a totally different mechanism.

\section{IV.2. Osaka Spinning Company and the emergence of new knowledge source}


The first seed of industry success was planted around the same time as the government started its promotion policies but was independent of those. It came from Eiichi Shibusawa, a pioneering industrialist who is often dubbed the "father of Japanese capitalism" (see, e.g., Tai, 1993). Shibusawa, whose career included serving in the inner circle of the last Prince Tokugawa, the top military ruler of pre-Meiji Japan, as well as a stint at Meiji government's Ministry of Finance (he left government service in 1873 to become a private entrepreneur), had successfully launched several companies, most prominently the First National Bank (the first modern bank in Japan), prior to entering cotton spinning. He started planning his mill, eventually called "Osaka Spinning Company," in 1879, that is, around the same time the government started building its Aichi National Mill.

Arguably, the most important thing that Shibusawa did differently from other contemporaneous firms was the decision to obtain his own technologically enlightened human capital by tapping into global knowledge. Takeo Yamanobe, a 26-year-old family acquaintance who had earlier gone to England to study economics of insurance at the University of London, agreed to transfer to the mechanical engineering department at Kings College, Cambridge, and then went to acquire practical skills at Rose Hill Mill in Blackburn, Lancashire, where he worked regular eight-hour shifts alongside spinning workers (see e.g., Abe, 2004). Yamanobe returned to Japan in July 1880 and was given the task of choosing the site and designing the projected mill.

Yamanobe not only became the chief engineer and later the CEO of Osaka Spinning Company (and its successor, Toyo Spinning), he also subsequently took over the institution of knowledge diffusion through the industry association and filled it with the right kind of knowledge (and approach; see more on this below). During the first half of the 1880s, however, the government was still in charge of the association, and this gives me an opportunity to compare technological choices made independently by Osaka Spinning with those that proliferated through the extant knowledge sharing mechanism.

A key novel element in Shibusawa's technology plan right from the beginning was constructing a much larger mill than the standard 2,000-spindle size of government-promoted mills (archival evidence shows that by 1880, perhaps even earlier, he had already decided that the scale of his mill would be at least 10,000 spindles; see Takamura, 1971, I: 64). The first issue that had to be addressed, of course, was securing enough capital. Shibusawa drew on his prior experience as the founder of First National Bank to declare a joint stock company, and proceeded to raise 
capital from a broad and diverse array of private investors. The initial list of Osaka Spinning Company shareholders counted 95 individuals, the largest of whom (Shibusawa himself) owned 12 percent of the total number of shares. ${ }^{x i i}$

The process of choosing the power source speaks to how much even Shibusawa and Yamanobe were influenced by the prevailing wisdom at Boren early on. For almost a year, Yamanobe, accompanied by Ishikawa, toured various potential sites looking to ensure enough hydropower for the projected mill. Only in late 1881 was the decision made to turn to the steam engine instead (which, of course, proved to be the ultimately correct decision). Since that moment, it appears that all the strategic technology decisions pertaining to Osaka Spinning Company's mill were firmly in the hands of Yamanobe who officially became the company's chief engineer as it was incorporated in May 1882.

Having spent only a few months at Cambridge attending cotton spinning engineering classes, and then less than a year at Rose Hill Mill, Yamanobe may not have yet been ready for a fully independent role (Saxonhouse, 1974; Abe, 2004). But the contacts he established while in Lancashire allowed him to draw on an entirely different source of knowledge than governmentaided mills. The two-story brick building that hosted the machines, which was also the first private facility in Japan to introduce electrical lighting, became a source of admiration (and subsequent imitation) throughout the industry. Different (and superior) technological choices were made with regard to machines as well. As mentioned, Ishikawa had chosen William Higgins and Sons whose machines did not fit the type of raw cotton available at the time to Japanese mills. Yamanobe worked with Platt Brothers of Oldham to customize their machines so that they could be adjusted as much as possible to handle short-staple domestically grown cotton (Farnie and Abe, 2000). This also marked the start of a long-term partnership between Platt Brothers and Japanese cotton spinners, something that became a central piece of the subsequent industry success (Saxonhouse, 1974). Moreover, realizing the limits to his own knowledge at the time, Yamanobe invited William Nield, a highly regarded veteran Platt Brothers engineer and millwright with vast international experience to guide his team. One of the young Japanese assigned to help Nield in this process (and learn from him), Katsumasa Okamura, subsequently recalled that "Nield ... had extremely precise knowledge of the technology and was also a very good teacher. All previous mills had been assembled by uneducated workers, guided by people who had worked for Satsuma's Kagoshima mill and themselves possessed only half-baked knowledge. Ours was ... the first time a Japanese 
cotton spinning mill started operating after being properly assembled and installed, and it made a huge difference" (Toyo Boseki, 1986, Vol. I, p. 26).

Powered by global connectedness that gave it access to new knowledge and superior technological and managerial choices, Osaka Spinning Company started operating in 1883 and quickly became the only profitable company in the industry at the time. The board of directors distributed much of those profits as dividends to shareholders, demonstrating clear awareness of the importance of building investors' confidence. As a result, the company was able to triple its capital (and the corresponding mill size) within just a few years, reaching over 30,000 spindles by 1886. In that year, Osaka Spinning Company was already more than 10 times large than other mills, and it alone accounted for more than 46 percent of all cotton yarn produced by the industry. As mentioned, it was in that year (from which, not coincidentally, the chronology of modern economic growth in Japan starts - see Ohkawa and Rosovsky, 1965) that the government decided to put an end to its promotion policies and to let the industry develop on its own.

\section{IV.3. Subsequent knowledge diffusion and the role of relational networks}

The emergence of Osaka Spinning Company gave the fledgling Japanese cotton spinning industry its first standout firm. After the government withdrew, independent private entrants started coming in. The total number of firms in the industry was 21 in 1886 but it doubled by the end of the decade and doubled once again by 1898. Many new entrants (and even some of the extant former government-aided firms), not surprisingly, chose to emulate Osaka Spinning Company's choices. The latter's leading role in determining the overall direction of the industry was cemented in 1888 when Boren was reorganized into the association of independent producers, its headquarters were moved to Osaka Spinning Company premises and Yamanobe became the new chairman. As noted below, the new leadership of Boren almost immediately took several crucial steps that put the industry on the right track, and more generally, the role of the association in diffusing the best practices can hardly be overestimated. At the same time, especially during the initial 5-10 years after the industry had been privatized, the degree of uncertainty and, most crucially, the dearth of suitable human capital were still severe. This created the situation where technological choices made by different firms were still quite different from each other and the eventual uniformity of the industry's practices emphasized, e.g., by Saxonhouse (1974) was still far from complete (see Braguinsky and Hounshell, 2015a). This gives me an opportunity to examine how the diffusion of 
"embodied" knowledge coming from different sources affected the choices made by different types of new entrants and how it played out in their outcomes.

Table 3 lists all firms that operated in the industry from its inception and until 1898, their sources of technological knowledge and some other characteristics; initial mill size, year the mill reached the minimum efficient size of 10,000 spindles (if at all), whether it has ever acquired another firm ("acquirer" or not), exit year (if exited before 1920) and whether the exit happened through acquisition (with the production facilities operating without interruption) or through bankruptcy or other reasons that led the mill to shut down its operations. The sources of technological knowledge were traced to prominent engineers (technologists) with independent backgrounds (such as the above-mentioned Masatatsu Ishikawa or Takeo Yamanobe) and assigned to firms based on an employment contract (for example, Yamanobe was the chief engineer of Osaka Spinning Company and Osaka Yoriito at the same time) or primary engineering advising role or the spinoff relationship (including former associates or apprentices).

As can be seen from Table 3, sources of technological knowledge could be traced to specific individuals (engineers) in 73 out of 93 total cases (cases where the sources remained unidentified are labeled "N/A" in the third column of Table 3 and mostly pertain to smaller local firms or firms with very short histories). Among those, 36 firms derived their technological knowledge from engineers with formal training (including those in advisory roles); nine firms, in the cluster centered around the city of Okayama in Western Japan were supervised or advised by Tomonao Ishiguro and Shin'ichiro Arakawa and their co-workers (Ishiguro was a college-educated engineer although in metallurgy, not cotton spinning, while Arakawa was among the first cohort of graduates of the Imperial College of Engineering), five firms were supervised or advised by Narazo Takatsuji (Imperial College of Engineering graduate); four firms each were supervised or advised by the already-mentioned Takeo Yamanobe and his protégé Tsunezo Saito (the Imperial College of Engineering graduate whom Yamanobe recommended for the chief engineer position at Mie Cotton Spinning), and by Kyozo Kikuchi and Hidehisa Shimoyama (also Imperial College of Engineering graduates); three firms had access to services of Seizaburo Kawai (another Imperial College of Engineering graduate), two firms each employed Takeshi Yamaguchi (Englisheducated engineer, although not in cotton spinning), Shun'ichi Hattori and Tomokichi Yoshida (the latter two Imperial College of Engineering graduates), and, finally, one firm was advised by 
England-educated Naosada Taniguchi. With the exception of Shimoyama, Kawai, and Yoshida, all the above engineers had experience in England.

Engineers mentioned above practically exhausted the list of all college-educated engineers available to cotton spinning firms in Japan in the late 1880s-early 1890s. It is therefore not surprising that many new entrants still had to resort to non-college-educated technical personnel. The most prolific source of knowledge for such firms remained Masatatsu Ishikawa, who retired from government service in 1887 but continued in his advisory role for the privatized industry, and his associates and apprentices. Thirteen new entrants relied on this source of knowledge, bringing the total number of firms under Ishikawa's influence to 21 and creating a situation in which it is possible to directly compare older and newer sources of knowledge in contemporaneous competition under the same market environment.

As it turns out, the new sources of knowledge generated by college-educated engineers played by far the most important role in the industry success, both overall and individual firms. A crucially important early instance came around 1887 when three of those (Hattori, Saito, and Kikuchi, all of them Imperial College graduates, Hattori and Saito just a year apart) found themselves in England sent there by their respective employers for training and to place orders for spinning machines at the same time. Aided also by Senjiro Watanabe, Mitsui Trading's representative in London, they arrived at an innovative decision to start importing to Japan ring spinning machines rather than mules that had been imported until that time (see, e.g., Tamagawa, 1997). The subsequent speed of diffusion of ring technology in Japan was the fastest in the world (Saxonhouse and Wright, 1984). Just about a year or so later, Boren, led by Yamanobe and his Osaka Spinning Company, organized a mission to India to study the possibility of importing Indian cotton to replace short-stapled Japanese and Chinese cotton which was not suitable for mechanized spinning and the use of which put severe limitations in the way of improved productivity and performance of Japanese mills. The almost simultaneous adoption of ring spinning technology and longer-stapled Indian (and later also the U.S.) cotton were the two most important factors that propelled the industry towards its spectacular success (see, e.g., Tamagawa, 1995; Braguinsky and Hounshell, 2015a). The tradition of knowledge sharing established under early Boren and continuing under Osaka Spinning Company leadership meant that the knowledge about the superiority of Indian cotton and ring spinning frames diffused extremely fast. Samples of yarn spun using Indian cotton were distributed to all firms, and Boren also negotiated a discount on 
shipping costs for imported cotton as well as the elimination of the (fairly low in any event) import tariff on raw cotton which applied equally to all its members. The actual adoption of those new technologies by individual firms, however, was also influenced by the sources of their individual technological knowledge.

Ring spinning machines became the universal choice for all mills that started operating after 1887 (the only exception was Nihon Spinning Company, which, led by Kikuchi, deliberately imported mules to experiment with higher-quality cotton yarn). After all, it only took emulating the orders placed by industry leaders, which did not require any particular skills (and was aided by the fact that all such orders went through the same London office of Mitsui Trading that had been involved in first purchases of ring machines). Employing longer-stapled Indian and U.S. cotton, on the other hand, turned out to be more difficult for some of them. The penetration of Indian and U.S. cotton and the phasing out of the Japanese and Chinese raw cotton took almost a decade and was only completed by the turn of the twentieth century. Most importantly, through this process individual mills developed their own proprietary technology of cotton mixing, something that, according to economic historians, qualifies as the first globally important innovation to emerge in the young cotton spinning industry in Japan and became one of the major sources of its international competitiveness (Saxonhouse and Wright, 2010).

The earliest firm-level data on different types of cotton input used by each individual mill are available for 1893. In that year non-Japanese and non-Chinese sources of cotton accounted for about fifty percent of the total amount of raw cotton consumed by the industry but there was wide variation across different mills. In Table 4 I present binary comparisons observed between the firms whose sources of knowledge came from college-educated engineers and all other firms; among the latter; I also distinguish between the firms that were guided by Ishikawa and all others. The comparisons show the differences in means of the combined fraction of Indian and U.S. cotton in the total amount of raw cotton consumed by each category of mills and in the degree to which they engaged in cotton mixing. This last metric ("cotton mixing index") was constructed as follows. I first assigned a dummy equal to 1 to each type of cotton if its usage in 1893 was 5 percent or more of the total quantity of cotton consumed by the mill and zero otherwise. I then added all these dummies together. For example, Osaka Spinning Company used 41.3 percent Chinese cotton and 54.3 percent Indian cotton in 1893, while other types constituted less than 5 percent of its total consumption, so its "cotton mixing index" assumes the value of 2 , and so on. 
The results show that the fraction of Indian and U.S. cotton in total in 1893 was more than twice as high in firms with college-educated engineers in charge than in all other firms (the difference is highly statistically significant). Such firms also had on average 3.3 different types of cotton accounting for at least 5 percent of their total cotton consumption, compared to 2.5 types for all other firms (the difference is statistically significant at the 5 percent level). In contrast, having Ishikawa or his associates as knowledge source did not render any advantage in terms of adopting imported cotton and developing cotton-mixing technology, as can be seen from the comparisons in the third row of Table 4. Thus, even in technological choices that were initiated and diffused through Boren, it was important to have the right kind of engineering personnel in charge of individual mills to take full advantage of superior technological opportunities.

The difference in the speed with which new industry-wide technological choices diffused across firms with different knowledge sources is also manifested in differences in capital-labor ratios and female to male factory operatives. Adopting ring spinning frames and especially cottonmixing technology required a shift toward lower capital-labor ratio (caused by an increase in the number of workers per spindle, including those employed in preparatory stages) and a shift towards a higher fraction of female operatives in their total number (Saxonhouse and Wright, 1984a; 2010). Table 5 presents binary comparisons similar to Table 4 along these two dimensions. Firms deriving their knowledge sources from college-educated engineers have markedly lower capital-labor ratios and higher female to male operatives ratio than all other firms. Here, Ishikawa-influenced firms can also be seen to be ahead of other firms with no college-educated engineers in charge, especially in the degree to which they relied on female labor force.

Differences in technological choices have a predictable impact also on firms' performance. In Table 6 I present the differences in mean total factor productivity and mean profitability between firms that derived their source of knowledge from college-educated engineers, from Ishikawa and his apprentices, and all other firms. Total factor productivity is measured as the residuals from estimating the production function as in equation (1) above; separate estimates of labor and capital productivity as in Table 1 above yield very similar results. For profitability, I utilize balance sheets data published in the association's monthly bulletin in 1893-94. These are not available for all firms, and the largest number of observations (on 33 firms) pertains to the first half of 1894 which are the data I utilize in Table 6 (using all available data leads to qualitatively similar results but introduces potential bias because of missing observations on some but not other firms). I employ 
the "return on assets" measure, which is the amount of profit (or loss) reported by the firm, divided by the total value of all assets on its balance sheet. It can be seen that firms with college-educated engineers as their knowledge source economically and statistically significantly outperformed all other firms in terms of both productivity and profitability of their operations. Thus, their technological choices were indeed superior. In contrast, firms that got supervision and/or advice from Ishikawa had both lower productivity and profitability than even firms that did not have college-educated engineers. These results are robust to excluding firms founded before 1887, that is, limiting the sample only to post-government promotion era entrants.

The knowledge diffusion process through the association eventually led to convergence in technological choices across firms, despite different idiosyncratic knowledge sources. As already mentioned, the penetration of ring spinning frames and imported raw cotton from India and the U.S. were by and large completed by the second half of the 1890s. In what follows I present some comparisons across firm categories above for the year 1898 which was one of the last years of the first phase of industry growth (see Figure 2 above) and also the last year of operations for some firms that went bankrupt and/or were acquired in late 1898-1899.

Table 7 confirms that technological practices were much more uniform by 1898 . The capital to labor ratios are by this time remarkably similar across all categories of firms and while the female to male operatives ratio is statistically higher in firms with sources of knowledge from college-educated engineers as compared to all other firms (and lower in Ishikawa-advised firms), the difference is much less in magnitude than it was in 1893 (Table 5 above) and economically is no longer significant. There is no economic or statistical difference across different firm categories in terms of total factor productivity in 1898 either, which is also a reflection of uniform technological practices as well as capital vintage differences (whereby newer entrants were able to take advantage of opportunities provided by imported raw cotton and order faster and more versatile machines for their mills_-see Braguinsky, Ohyama, Okazaki, and Syverson, 2015). Nevertheless, as shown in Table 8, the all-important profitability, mill size and exporter status outcomes are still very different. Specifically, firms with college-educated engineers as their knowledge source are more than 2.5 times larger than all other firms, their average returns on assets are higher than in other firms, and they are also much more likely to be among exporting firms. Notably, firms in the Ishikawa network also separated themselves by 1898 from the rest of the industry - their mean returns on assets are actually economically and statistically the same as 
in firms with college-educated engineers, while their propensity to be exporters is in-between the firms led by college-educated engineers and the rest of the industry.

\section{Some lessons}

The "nanoeconomic" analysis of knowledge diffusion in the Meiji-era Japanese cotton spinning industry revealed findings that are consistent with the stylized facts discovered by an array of previous studies mentioned in the Introduction.

First, even though not the first entrant, Osaka Spinning Company was the first standout firm in the industry and the initial blueprint for success was almost entirely its creation.

Second, knowledge, both good and bad, was indeed transmitted through an "embodied" channel. Yamanobe, the Osaka Spinning's chief engineer's experience and contacts in England played the crucial role in acquiring and transmitting the right kind of knowledge, as did similar experiences and contacts of other leading engineers (such as Saito of Mie Spinning, Kikuchi of Hirano, Settsu, Amagasaki, and Nihon Spinning, Sanji Muto of Kanegafuchi Spinning - he was unique in being not an engineer but a professional manager and his experience was in the U.S.). But the government appointee (Ishikawa)'s influence led to wrong technological choices, at least initially, and almost led the whole industry astray.

Third, good knowledge eventually won through competition. Idiosyncratic knowledge sources continued to play an important role in individual firms, and only through competitive pressures (exit versus expansion, including through acquisitions) did the industry eventually converge to the best practices.

At the same time, the analysis above provides us with some new insights into the two research questions posed in Section II.2, namely, what the most important factors for knowledge diffusion are, and how to make sure that the knowledge being diffused is of the right kind.

Early on, Japanese cotton spinning industry was a typical candidate for failure - with no established knowledge base and no independent financing sources; the measures taken by the government were misguided both in terms of incentives and, even more so, in terms of promoting and diffusing wrong technological and managerial solutions.

The success of the industry came through private initiative. Even though Japan at the time was a developing nation, and capital accumulation was at a very low level, a way was found to generate access to much-needed initial finance through the system of "business promoters" whose 
role was to coordinate private investors and provide monitoring services (Miyamoto, 2010, Ch. 3, 5; see also Miwa and Ramseyer, 2000). Indeed, Eiichi Shibusawa who founded Osaka Spinning Company is widely recognized as the most prominent such promoter. Importantly, Shibusawa elected not to rely on government assistance, but instead tapped into a global knowledge source. This created a solid foundation for building a competitive high-tech industry for the first time.

In terms of mechanisms for knowledge diffusion process early in the industry life-cycle, the most important lessons from the story presented in this paper can be summarized as follows. First, a collaborative institutional arrangement by itself is not a guarantee of the diffusion of the best practices. The Meiji government deserves credit for creating Boren as an institution for knowledge diffusion, but its first six years present a stark reminder that such an institutional arrangement is a double-edged sword, and can easily lead the industry astray if wrong choices are made at the outset by unqualified leadership. Second, and related, diversity of knowledge sources and their unfettered competition (even as the firms also cooperated with each other) were the main reason why the industry found the right way and ended up with the right kind of enlightened human capital for successful technology adoption and diffusion.

Japan's Meiji-era cotton spinning industry has been cited in the literature as an example of almost seamless technology adoption through the action of the industry association acting as a single, cooperative decision-making unit. In fact this is hardly the case. Nanoeconomic, firm- and individual-level analysis shows that the main reason why the industry's catch up could be completed in what was indeed historically rather short period of time was that the environment fostered superior human capital, whose better ideas had a chance to prove themselves and prevail through competition in markets for inputs, output and assets (both physical and human). 


\section{References}

Abe, T. (2004), 'Technological and organizational absorption in the development of the modern Japanese cotton industry,' Paper presented at the GENH $5^{\text {th }}$ conference "Textiles," Osaka, Japan.

Agarwal, R. and M. Gort (2001), 'First-mover advantage and the speed of competitive entry, 18871986,' Journal of Law and Economics, 44(2), 161-177.

Agarwal, R. and B. Bayus (2002), 'The market evolution and sales takeoff of product innovations,' Management Science, 48(8), 1024-1041.

Agarwal, R., R. Echambadi, A. Franco and M.B. Sarkar (2004), 'Knowledge transfer through inheritance: spin-out generation, development, and survival,' Academy of Management Journal, 47(4), 501-522.

Agarwal, R. and S. Braguinsky (2015), 'Industry evolution and entrepreneurship: Steven Klepper's contributions to industrial organization, strategy, technological change and entrepreneurship,' Strategic Entrepreneurship Journal, forthcoming.

Allen, R. (1983), 'Collective invention,' Journal of Economic Behavior and Organization, 4(1), $1-24$.

Avnimelech, G. and M. Teubal (2004), 'Venture capital policy in Israel: a comparative analysis and lessons for other countries,' in A. Bartzokas and S. Mani (eds.), Financial System, Corporate Investment in Innovation and Venture Capital. Edward Elgar: London, UK.

Bernhofen, D. and J. Brown (2004), 'A direct test of the theory of comparative advantage: the case of Japan,' Journal of Political Economy, 112(1), 48-67.

Boldrin, M. and D. Levine (2010), Against Intellectual Monopoly. Cambridge University Press, New York, NY.

Braguinsky, S., S. Gabdrakhmanov and A. Ohyama (2007), 'A theory of industry dynamics with innovation and imitation,' Review of Economic Dynamics, 10(4), 729-760.

Braguinsky, S. and S. Klepper (2009), 'Worker Mobility and Growth: The Goose that Laid the

Golden Eggs,' In A. Monsarat and K. Skinner (eds.), Renewing Globalization and Economic Growth in a Post-Crisis World. Carnegie Mellon University Press: Pittsburgh, PA, pp. 29-31.

Braguinsky, S. and D. Rose (2009), 'Competition, cooperation, and the neighboring farmer effect,' Journal of Economic Behavior and Organization, 72(1), 361-376.

Braguinsky, S. and D. Hounshell (2015a), 'Spinning tales about Japanese cotton spinning: Saxonhouse (1974) and lessons from the new data,' Journal of Economic History, 75(2), 364-404.

Braguinsky, S. and D. Hounshell (2015b), 'History and nano-economics in strategy and industry evolution research: lessons from the Meiji-era Japanese cotton spinning industry,' Strategic Management Journal, forthcoming.

Braguinsky, S., A. Ohyama, T. Okazaki and C. Syverson (2015), 'Acquisitions, productivity, and profitability: evidence from the Japanese cotton spinning industry,'American Economic Review, 105(7), forthcoming. 
Cobbing, A. and T. Inuzuka (2000), The Satsuma Students in Britain. Japan's Early Search for the 'Essence of the West'. Japan Library: Surrey, UK.

Conley, T., and C. Udri (2010), 'Learning about a new technology: Pineapple in Ghana.' American Economic Review, 101(1), 35-69.

Enkakukiji (1900), Nihon Menshi Bōseki Enkakukiji (The History of Japan's Cotton Spinning, in Japanese), Dainihon Bōseki Rengōkai, unpublished.

Farnie, D. and T. Abe (2000), 'Japan, Lancashire and the Asian market for cotton manufactures, 1890-1990,' in D. Farnie, T. Nakaoka, D. Jeremy, J. Wilson T. and Abe (eds.), Region and Strategy in Britain and Japan: Business in Lancashire and Kansai, 1890-1990. Routledge: London, UK and New York, NY.

Fischoff, B. (1980), 'For those condemned to study the past: reflections on historical judgment,' New Directions for Methodology of Social and Behavioral Science, 4,79-93.

Foster, A. and M. Rosenzweig (1995), 'Learning by doing and learning from others: human capital and technical change in agriculture,' Journal of Political Economy, 103(6), 1176-1209.

Geppō (Monthly Bulletin of the Japanese Cotton Spinners' Association) (1889-1920). Dainihon Bōseki Rengōkai, various issues, in Japanese.

Gilson, R. (1999), 'The legal infrastructure of high technology industrial districts: Silicon Valley, Route 128, and covenants not to compete,' New York University Law Review, 74, 575-629.

Goldfarb, B., D. Kirsch and A. Shen (2012), 'Finance of new industries,' in D. Cumming (ed.), The Oxford Handbook of Entrepreneurial Finance. Oxford University Press: Oxford, UK.

Gort, M. and S. Klepper (1982), 'Time paths in the diffusion of product innovations,' Economic Journal, 92, 630-653.

Grossman, G. and E. Helpman (1991), Innovation and Growth in the Global Economy. MIT Press: Cambridge, MA.

Hausmann, R. and D. Rodrik (2003), 'Economic development as self-discovery,' Journal of Development Economics, 72(2), 603-633.

Hirschmeier, J. (1965), 'Shibusawa Eiichi: industrial pioneer,' in W. Lockwood (ed.), The State and Economic Enterprise in Japan. Princeton University Press: Princeton, NJ, pp. 209-48.

Hounshell, D. and J. Smith (1988), Science and Corporate Strategy. Cambridge University Press: Cambridge, UK.

Isaacson, W. (2011), Steve Jobs. Simon and Schuster: New York, NY.

Jovanovic, B. and G. MacDonald (1994), "The Life Cycle of a Competitive Industry," Journal of Political Economy, 102(2), 322-47.

Kampō (Official Gazette) (1883-1889), Dajōkan Bunshokyoku (Cabinet Document Bureau), in Japanese.

Kinugawa, T. (1964), Hompo Menshi Boseki Shi (History of the Japanese Cotton Spinning Industry). Hara Shobo: Tokyo, Japan, 7 vols., in Japanese..

Kiriazidou, E. and M. Pesendorfer (1999), 'Viennese chairs: a case study for modern industrialization,' Journal of Economic History, 59(1), 143-166. 
Klepper, S. (1996), 'Entry, exit, growth, and innovation over the product life cycle,' American Economic Review, 86(3), 562-583.

Klepper, S. (2009), 'Silicon Valley - a chip off the Old Detroit Bloc', in Z. Acs, D. Audretsch, and R. Strom (eds.), Entrepreneurship, Growth, and Public Policy. Cambridge University Press: Cambridge, MA, pp. 79-115.

Klepper, S. (2010), 'The origin and growth of industry clusters: the making of Silicon Valley and Detroit,' Journal of Urban Economics, 67, 15-32.

Klepper, S. (2011), 'Nano-economics, spinoffs, and the wealth of regions,' Small Business Economics, 37, 141-154.

Klepper, S. (2016), Experimental Capitalism: The Nanoeconomics of American High-Tech Industries. Edited by S. Braguinsky, D. Hounshell, and J. Miller. Princeton University Press: Princeton, NJ.

Klepper, S. and K. Simons (2000), 'The making of an oligopoly: firm survival and technological change in the evolution of the U.S. tire industry,' Journal of Political Economy, 108(4), 728-760.

Klepper, S. and P. Thompson (2010), 'Disagreements and intra-industry spinoffs,' International Journal of Industrial Organization, 28, 526-538.

Kōkajō (Company reports) (1896-1920), Osaka University Library: Osaka, Japan, in Japanese.

Landes, D. (1965), 'Japan and Europe: contrasts in industrialization,' in W. Lockwood (ed.), The State and Economic Enterprise in Japan. Princeton University Press: Princeton, NJ, pp. 93-182.

Lerner, J. (2009), Boulevard of Broken Dreams. Why Public Efforts to Boost Entrepreneurship and Venture Capital Have Failed - And What to Do About It. Princeton University Press: Princeton, NJ.

Lucas, R. (1988), 'On the mechanics of economic development,' Journal of Monetary Economics, 22, 3-42.

Marx, M., D. Strumsky and L. Fleming (2009), 'Noncompetes and inventor mobility: specialists, stars, and the Michigan experiment,' Management Science, 55(6), 875-889.

Mathews J, (1997), 'A Silicon Valley of the east: creating Taiwan's semiconductor industry,' California Management Review, 39(4), 26-54.

Meyer, P. (2003), 'Episodes of collective invention,' Working Paper, U.S. Bureau of Labor Statistics, No. 368.

Miwa, Y. and M. Ramseyer (2000), 'Corporate governance in transitional economies: lessons from the prewar Japanese cotton textile industry,' Journal of Legal Studies, 9(1), 171-203.

Miyamoto, M. (2010), Nihon Kigyou Keiei-shi Kenkyu (Japanese Business in Historical Perspective). Yuhikaku: Tokyo, Japan, in Japanese.

Moeen, M. and R. Agarwal (2014), 'Incubation of innovation ecosystems in nascent industries: the role of pre-investment capabilities in value capture,' Working Paper, University of North Carolina, NC. 
Moll, B. (2014), 'Productivity losses from financial frictions: can self-financing undo capital misallocation?,' American Economic Review, 104(10), 3186-3221.

Morosini, P. (2004), 'Industrial clusters, knowledge integration and performance,' World Development, 32(2), 305-326.

Mostafa, R. and Klepper, S. (2011), 'Industrial development through tacit knowledge seeding: evidence from the Bangladesh garment industry,' Working Paper, Carnegie Mellon University, Pittsburgh, PA.

Nawa, T. (1937), Nihon-no Bosekigyo-to Genmen Mondai Kenkyu (A Study of Japanese Cotton Spinning Industry and the Raw Cotton Problem). Daido Shoin: Osaka, Japan, in Japanese.

Nihon Chōki Tōkei Sōran (Historical Statistics of Japan) (1987). Japan Statistical Association, 4 vols., in Japanese.

Nōshōkōmu Tōkei Nempō (Statistics on Agriculture, Commerce and Industry) (1896-1911), Nōshōkōmusho (Ministry of Agriculture, Commerce and Industry), Japan, in Japanese.

Nuvolari, A. (2004), 'Collective invention during the British industrial revolution: the case of the Cornish pumping engine,' Cambridge Journal of Economics, 28(3), 347-363.

Ohyama, A., S. Braguinsky and K.M. Murphy (2004), "Entrepreneurial ability and market selection in an infant industry: evidence from the Japanese cotton spinning industry,' Review of Economic Dynamics, 7(2), 354-381.

Ohkawa, K. and Rosovsky, R. (1965), 'A century of Japanese economic growth,' in W. Lockwood (ed.), The State and Economic Enterprise in Japan. Princeton University Press, Princeton, NJ, pp. 47-92.

Okamoto, Y. (1995), Meiji-ki Boseki Gijutsu Kankeishi (History of Technology in Meiji-Era Cotton Spinning. Kyushu Daigaku Shuppankai (Kyushu University Press): Fukuoka, Japan, in Japanese.

Pietrobelli C. and R. Rabelotti (2004), "Upgrading in clusters and value chains in Latin America: the role of policies,' IDB Publication No. 40778, Inter-American Development Bank.

Ranis, G., and G. Saxonhouse, 1985, 'Determinants of TechNology Choice: The Indian and Japanese Cotton Industries,' in K. Ohkawa and G. Ranis (eds), Japan and the Developing Countries. Oxford: Basic Blackwell, pp. 135-54.

Rodrik, D. (2014), 'The past, present, and future of economic growth,' in F. Allen, J. Behrman, N. Birdsall, A. Fardoust, D. Rodrik, A. Steer and A. Subramanian (eds.), Towards a Better Global Economy. Oxford University Press, Oxford, UK, pp. 70-119.

Romer, P. (1990), “Endogenous technological change,' Journal of Political Economy, 98(5, Pt. 2), S71-102.

Rosenberg, N. (1972), "Factors affecting the diffusion of technology,' Explorations in Economic History, 10, 3.

Saxenian, A. (1994), Regional Advantage: Culture and Competition in Silicon Valley and Route 128. Cambridge, MA: Harvard University Press.

Saxonhouse, G. (1971), 'Productivity change in the Japanese cotton spinning lindustry, 18911935,' Unpublished Ph.D. Dissertation, Yale University, CT. 
Saxonhouse, G. (1974), 'A tale of Japanese technological diffusion in the Meiji period,' Journal of Economic History, 34, 149-165.

Saxonhouse, G. and G. Wright (1984), 'Rings and mules around the world: a comparative study in technological choice,' in G. Saxonhouse and G. Wright (eds.), Technique, Spirit and Form in the Making of the Modern Economies: Essays in the Honor of William N. Parker. Research in Economic History, Supplement 3. JAI Press: London, UK, pp. 271-300.

Saxonhouse, G. and G. Wright (2010), 'National leadership and competing technological paradigms: the globalization of cotton spinning, 1878-1933,' Journal of Economic History, 70(3), 535-566.

Smith, T. (1955), Political Change and Industrial Development in Japan: Government Enterprise, 1868-1880. Stanford University Press: Stanford, CA.

Spencer, J. (2003), 'Firms' knowledge-sharing strategies in the global innovation system: empirical evidence from the flat panel display industry,' Strategic Management Journal, 24, 217-233.

Takamura, N. (1971), Nihon Bosekigyoshi Josetsu (Introduction to the History of the Japanese Cotton Spinning. Hanawa Shobo: Tokyo, Japan, 2 vols., in Japanese.

Tai, K. (1993), 'Confucianism and Japanese modernization: a study of Shibusawa Eiichi,' in S. Durlabhjl and N. Marks (eds.), Japanese Business: Cultural Perspectives. State University of New York Press: Albany, NY, pp. 43-56.

Tamagawa, K. (1995), 'Waga Kuni Menshi Bōseki Kikai-no Hatten-ni Tsuite' (On the Development of Cotton Spinning Technology in Japan), Gijutsu-to Bunmei, 9(2), 1-20, in Japanese.

Tamagawa, K. (1997), 'Shoki Nihon Menshi Bōseki-ni-okeru Ringu Seibōki Dōnyu-ni Tsuite' (On the Adoption of Ring Spinning Frames in Early-Stage Japanese Cotton Spinning), Gijutsu-to Bunmei, 10(2), 1-26, in Japanese.

Tilton, J. (1971), International Diffusion of Technology: The Case of Semiconductors. Brookings Institution: Washington, D.C.

Toyo Boseki, (1986), Toyoboseki Hyakunenshi (One hundred years of Toyo Boseki). Toyobo: Osaka, Japan, in Japanese.

Wright, G. (2011), Cotton Spinning Machinery Orders, British Textile Machinery Firms, 18781933. ICPSR27141-v1. Ann Arbor, MI: Inter-university Consortium for Political and Social Research [distributor], 2011-11-18. doi:10.3886/ICPSR27141.v1. 
Figure 1. Japan's domestic output, import and export of cotton yarn (1883-1890)

1,000 pounds

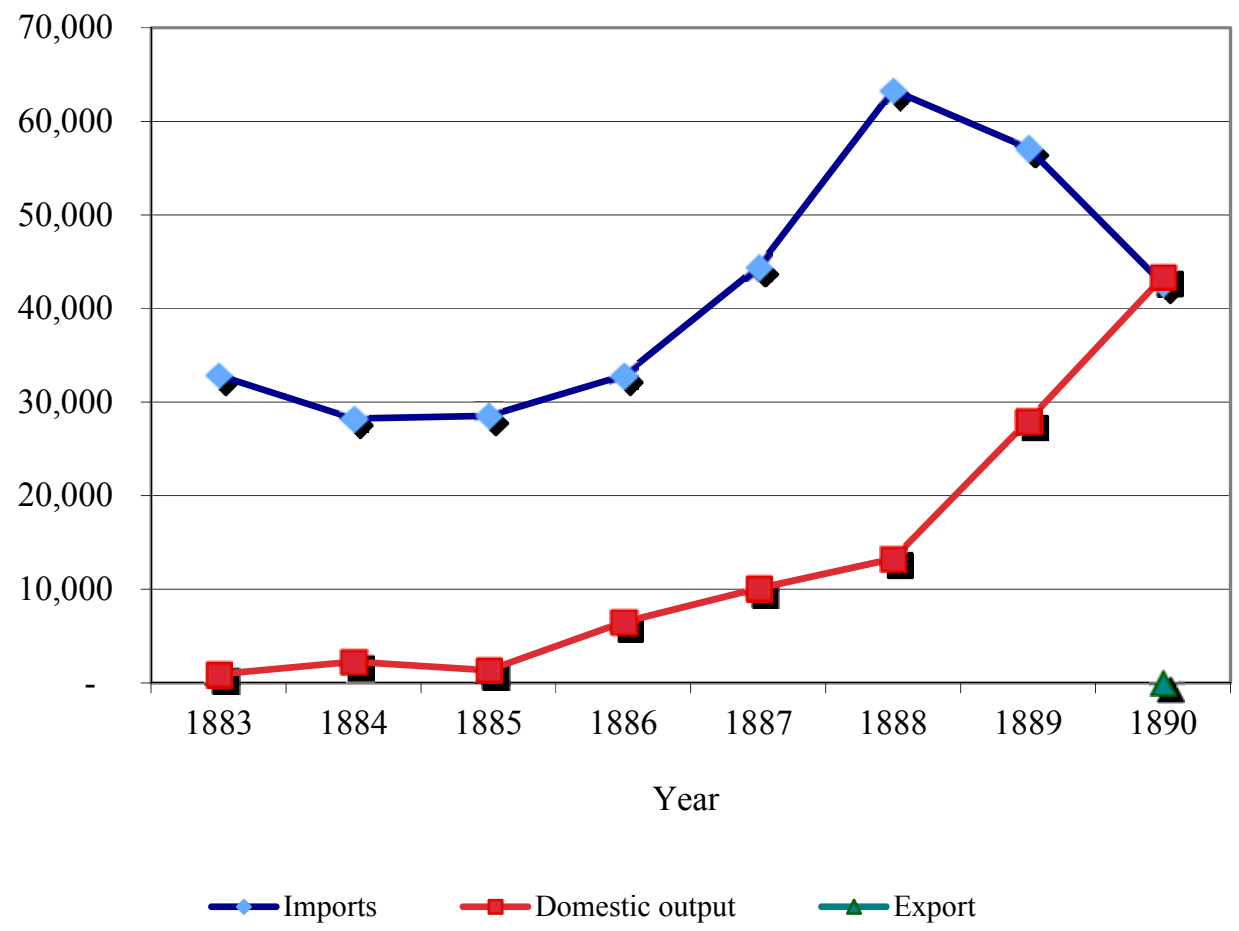

Source: For years 1887-90 "Nihon Choki Tokei Soran" (Long-Term Statistics of Japan), 1987; for years 1883-86 my estimates based on the totals for all firms listed in "Kampo" ("Official Gaztette"). The data for 1883 are available only for 6 months, while for 1884-85 these are available for 8 months and for 10 months in 1886 . To estimate annual output I have multiplied the total output for all available months by 2 in 1883 , by 1.5 in $1884-85$ and by 1.2 in 1886 . 
Figure 2. Japan's domestic output, import and export of cotton yarn (1891-1900)

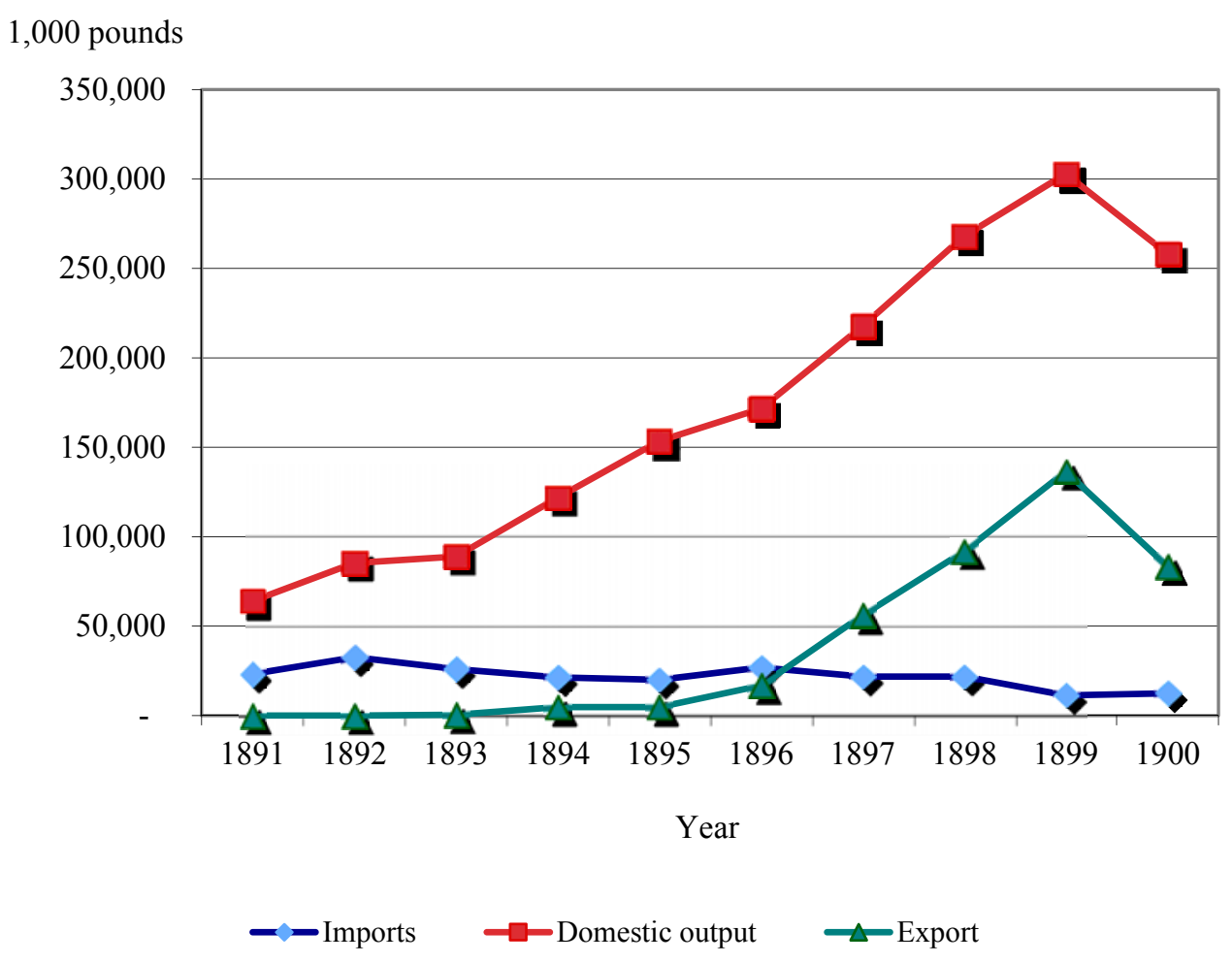

Source: "Nihon Choki Tokei Soran" (Long-Term Statistics of Japan), 1987. 
Table 1. Productivity of government-owned and subsidized firms supervised and not supervised by Ishikawa in 1883-86.

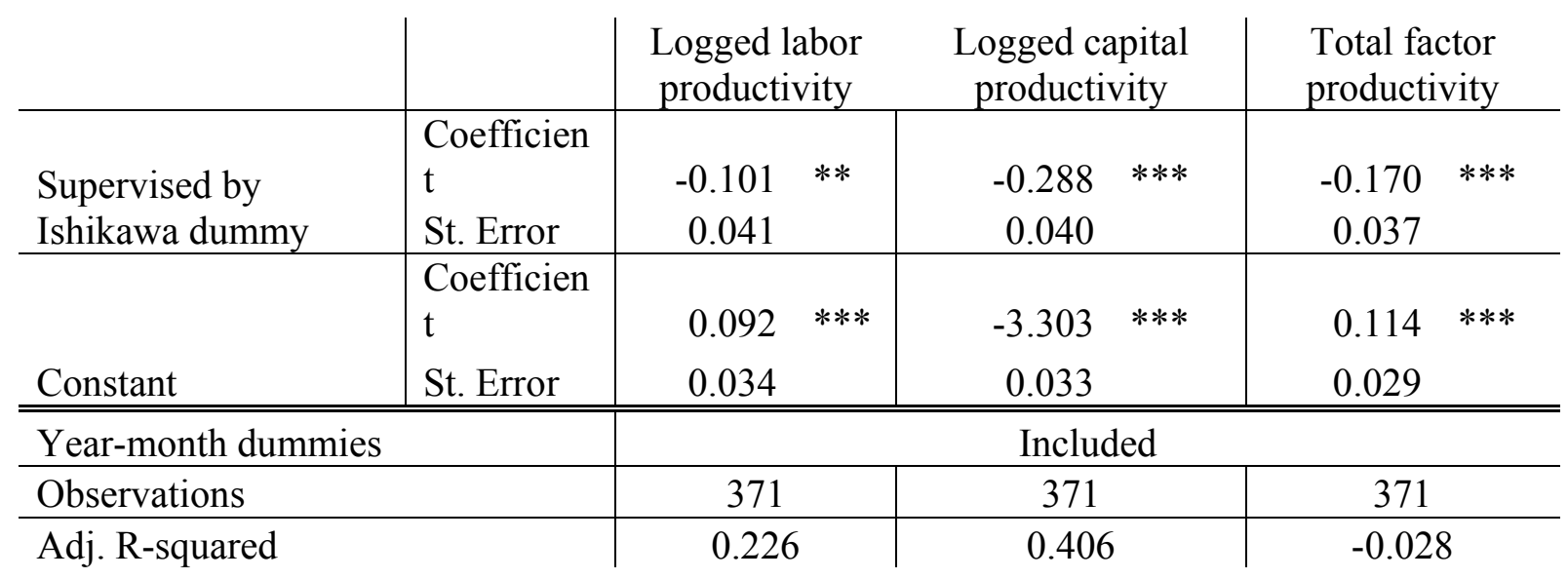

Note: The total number of firms is 19, 11 of them supervised by Ishikawa and 8 not supervised. Available monthly data on firm operations for years 1883-1886 (32 months total). Labor productivity is calculated as monthly output (in weight units), divided by total number of worker-days employed; capital productivity is calculated as monthly output (in weight units), divided by the total number of spindle-days in operation. Multifactor productivity is calculated as the residual from the production function estimated by OLS with logged output as the dependent variable, and logged spindle-days in operation, logged worker-days employed and year-month dummies as independent variables.

Table 2. Technology choices of government-owned and subsidized mills supervised and not supervised by Ishikawa in 1883-86

\begin{tabular}{|c|c|c|c|c|}
\hline & & $\begin{array}{l}\text { Supervised by } \\
\text { Ishikawa }\end{array}$ & $\begin{array}{l}\text { Not supervised by } \\
\text { Ishikawa }\end{array}$ & \\
\hline $\begin{array}{l}\text { Size (number of spindles } \\
\text { installed) }\end{array}$ & $\begin{array}{l}\text { Mean } \\
\text { St. Error }\end{array}$ & $\begin{array}{r}2,196 \\
86 \\
\end{array}$ & $\begin{array}{r}2,200 \\
109 \\
\end{array}$ & \\
\hline Powered by water engines & $\begin{array}{l}\text { Mean } \\
\text { St. Error }\end{array}$ & $\begin{array}{l}0.70 \\
0.03\end{array}$ & $\begin{array}{l}0.24 \\
0.03\end{array}$ & $* * *$ \\
\hline Capital to labor ratio & $\begin{array}{l}\text { Mean } \\
\text { St. Error }\end{array}$ & $\begin{array}{r}38.39 \\
0.97 \\
\end{array}$ & $\begin{array}{r}32.36 \\
1.15 \\
\end{array}$ & $* * *$ \\
\hline $\begin{array}{l}\text { Female to male operatives } \\
\text { ratio }\end{array}$ & $\begin{array}{l}\text { Mean } \\
\text { St. Error }\end{array}$ & $\begin{array}{l}2.61 \\
0.07\end{array}$ & $\begin{array}{l}1.98 \\
0.04\end{array}$ & $* * *$ \\
\hline
\end{tabular}

Note: See Table 1. *** indicates that the difference in means is statistically significant at the 1 percent level, using a double-sided $t$-test with unequal variance. 
Table 3. Sources of technological knowledge

\begin{tabular}{|c|c|c|c|c|c|c|c|}
\hline Mill name & $\begin{array}{l}\text { Year started } \\
\text { operating }\end{array}$ & $\begin{array}{l}\text { Technological } \\
\text { knowledge source }\end{array}$ & $\begin{array}{l}\text { Initial mill size } \\
\text { (spindles) }\end{array}$ & $\begin{array}{l}\text { Year reached } \\
10,000 \text { spindles }\end{array}$ & Acquirer & Exit year & $\begin{array}{l}\text { Exited by } \\
\text { acquisition }\end{array}$ \\
\hline Kagoshima & 1867 & British advisors & 3,648 & N/A & No & 1898 & No \\
\hline Sakai & 1870 & Ishikawa & 2,000 & N/A & No & 1889 & No \\
\hline Kashima & 1872 & Unosuke Kashima & 720 & $\mathrm{~N} / \mathrm{A}$ & No & 1889 & No \\
\hline Dojima) & 1880 & Yamanobe/Saito* & 2,440 & 1891 & No & 1896 & No \\
\hline Himeji & 1880 & Yamao & 2,000 & N/A & No & 1899 & No \\
\hline Aichi National & 1881 & Ishikawa & 2,000 & N/A & No & 1896 & No \\
\hline Ichikawa & 1882 & Ishikawa & 2,000 & $\mathrm{~N} / \mathrm{A}$ & No & 1914 & Yes \\
\hline Kawashima & 1882 & Ishikawa & 2,000 & N/A & No & \multicolumn{2}{|c|}{ Evolved into Mie } \\
\hline Kuwanohara & 1882 & Ishikawa & 2,000 & N/A & No & 1900 & No \\
\hline Okayama & 1882 & Ishiguro/Arakawa* & 2,000 & 1893 & Yes & 1907 & Yes \\
\hline Shimomura & 1882 & Ishikawa & 2,000 & N/A - & No & 1912 & No \\
\hline Tamashima & 1882 & Ishiguro/Arakawa* & 2,000 & 1888 & No & 1898 & No \\
\hline Hiroshima & 1883 & Ishikawa & $2,000 \times 2$ & N/A & No & $\mathrm{N} / \mathrm{A}$ & N/A \\
\hline Miyagi & 1883 & Kashima & 2,000 & N/A & No & 1912 & No \\
\hline Osaka & 1883 & Yamanobe/Saito* & 10,500 & 1883 & Yes & $\mathrm{N} / \mathrm{A}$ & $\mathrm{N} / \mathrm{A}$ \\
\hline Nagasaki & 1884 & $\mathrm{~N} / \mathrm{A}$ & 2,000 & N/A & No & 1892 & No \\
\hline Shimada & 1884 & Ishikawa & 2,000 & $\mathrm{~N} / \mathrm{A}$ & No & 1917 & No \\
\hline Toyoi & 1884 & Ishikawa & 2,000 & N/A & No & 1895 & No \\
\hline Enshu & 1885 & Ishikawa & 2,000 & $\mathrm{~N} / \mathrm{A}$ & No & 1899 & $\mathrm{No}$ \\
\hline Nagoya & 1885 & Ishikawa & 4,000 & 1889 & No & 1905 & Yes \\
\hline Shimotsuke & 1885 & Ishikawa & 2,000 & 1910 & No & 1911 & Yes \\
\hline Osaka Yoriito & 1887 & Yamanobe/Saito* & 4,608 & N/A & No & 1903 & Yes \\
\hline Fujii & 1888 & Ishiguro/Arakawa* & 1,136 & N/A & No & 1902 & No \\
\hline Kofu & 1888 & Ishikawa & 2,064 & N/A & No & 1907 & No \\
\hline Mie & 1888 & Yamanobe/Saito* & 10,440 & 1888 & Yes & $\mathrm{N} / \mathrm{A}$ & N/A \\
\hline Naniwa & 1888 & Suzuki & 4,500 & 1889 & No & 1898 & No \\
\hline Tenma & 1888 & Kawai* & 6,864 & 1889 & No & 1899 & Yes \\
\hline Hirano & 1889 & Kikuchi* & 4,992 & 1890 & Yes & 1902 & Yes \\
\hline Kanegafuchi & 1889 & Yoshida* & 30,356 & 1889 & Yes & $\mathrm{N} / \mathrm{A}$ & $\mathrm{N} / \mathrm{A}$ \\
\hline Kurashiki & 1889 & Yamaguchi* & 4,472 & 1894 & Yes & N/A & $\mathrm{N} / \mathrm{A}$ \\
\hline Owari & 1889 & Hattori* & 15,360 & 1889 & No & 1905 & Yes \\
\hline
\end{tabular}




\begin{tabular}{|c|c|c|c|c|c|c|c|}
\hline Tokyo & 1889 & Kashima & 9,104 & 1894 & No & 1914 & Yes \\
\hline Wakayama & 1889 & Ishikawa & 4,044 & 1893 & No & 1911 & Yes \\
\hline Yawata & 1889 & Suzuki & 2,000 & N/A & No & 1890 & No \\
\hline Saitama & - & Shimoyama* & 2,000 & N/A & No & 1890 & No \\
\hline Kanakin & 1890 & Takatsuji* & 13,552 & 1890 & Yes & 1906 & Yes \\
\hline Shodoshima & 1890 & Ishiguro/Arakawa* & 2,016 & N/A & No & 1899 & Yes \\
\hline Uwa & 1890 & Suzuki & 2,064 & 1896 & No & 1902 & No \\
\hline Amagasaki & 1891 & Kikuchi* & 11,136 & 1891 & Yes & N/A & N/A \\
\hline Kurume & 1891 & Ishikawa & 5,160 & 1895 & No & 1899 & Yes \\
\hline Miike & 1891 & Shimoyama* & 10,368 & 1890 & Yes & 1902 & Yes \\
\hline Senshu & 1891 & Kawai* & 10324 & 1891 & No & 1903 & Yes \\
\hline Settsu & 1891 & Kikuchi* & 19,968 & 1890 & Yes & 1918 & Yes \\
\hline Yamashiro & 1891 & N/A & 1152 & N/A & No & 1898 & No \\
\hline Fukuyama & 1893 & Ishiguro/Arakawa* & 4608 & 1897 & No & 1903 & Yes \\
\hline Iyo & 1893 & N/A & 5376 & $\mathrm{~N} / \mathrm{A}$ & No & 1903 & Yes \\
\hline Tenma Orimono & 1893 & $\mathrm{~N} / \mathrm{A}$ & 2064 & 1909 & No & N/A & $\mathrm{N} / \mathrm{A}$ \\
\hline Asahi & 1894 & Yamaguchi* & 14924 & 1894 & No & 1898 & No \\
\hline Fukushima & 1894 & Ishikawa & 8256 & 1895 & Yes & $\mathrm{N} / \mathrm{A}$ & N/A \\
\hline Kishiwada & 1894 & Suzuki & 10368 & 1894 & Yes & $\mathrm{N} / \mathrm{A}$ & N/A \\
\hline Koriyama & 1894 & Ishikawa & 5326 & 1895 & No & 1907 & Yes \\
\hline Matsuyama & 1894 & N/A & 4992 & 1907 & No & 1918 & Yes \\
\hline Meiji & 1894 & Hagino & 7668 & 1896 & No & 1902 & Yes \\
\hline Onagigawa & 1894 & Shimoyama* & 4060 & N/A & No & 1903 & Yes \\
\hline Sakai & 1894 & $\mathrm{~N} / \mathrm{A}$ & 5376 & 1896 & Yes & 1917 & Yes \\
\hline Takaoka & 1894 & Kawai* & 5096 & 1899 & No & 1915 & Yes \\
\hline Wakayama & 1894 & Ishikawa & 5696 & 1910 & Yes & $\mathrm{N} / \mathrm{A}$ & $\mathrm{N} / \mathrm{A}$ \\
\hline Banyo Seimai & 1895 & N/A & 2184 & N/A & No & 1900 & No \\
\hline Kashiwazaki & 1895 & N/A & 2304 & $\mathrm{~N} / \mathrm{A}$ & No & 1901 & Yes \\
\hline Kumamoto & 1895 & Shimoyama* & 4608 & 1897 & No & 1899 & Yes \\
\hline Noda & 1895 & N/A & 4992 & 1897 & No & 1898 & Yes \\
\hline Tsushima & 1895 & Ishikawa & 9216 & 1897 & No & 1906 & Yes \\
\hline Ajino & 1896 & N/A & 6912 & N/A & No & 1903 & Yes \\
\hline Awaji & 1896 & N/A & 5000 & 1898 & No & 1900 & Yes \\
\hline Fushimi & 1896 & Takatsuji* & 10864 & 1896 & No & 1900 & Yes \\
\hline
\end{tabular}




\begin{tabular}{|c|c|c|c|c|c|c|c|}
\hline Harima & 1896 & Yamao & 10368 & 1896 & No & 1912 & Yes \\
\hline Heian & 1896 & N/A & 7156 & 1900 & Yes & 1903 & No \\
\hline Ise & 1896 & Ishiguro/Arakawa* & 2940 & $\mathrm{~N} / \mathrm{A}$ & No & 1900 & Yes \\
\hline Kasaoka & 1896 & Ishiguro/Arakawa* & 9984 & 1899 & No & 1909 & Yes \\
\hline Kuwana & 1896 & Hattori* & 3840 & 1897 & No & 1907 & Yes \\
\hline Kyoto & 1896 & Takatsuji* & 2304 & 1897 & No & 1901 & Yes \\
\hline Nihon & 1896 & Kikuchi* & 44160 & 1896 & Yes & 1916 & Yes \\
\hline Sanshugumi & 1896 & $\mathrm{~N} / \mathrm{A}$ & 960 & $\mathrm{~N} / \mathrm{A}$ & No & 1900 & No \\
\hline Bizen & 1897 & Ishiguro/Arakawa* & 6144 & 1898 & No & 1907 & Yes \\
\hline Hakata Kinuwata & 1897 & Ishiguro/Arakawa* & 5760 & 1898 & No & 1902 & Yes \\
\hline Ichinomiya & 1897 & Hagino & 10780 & 1897 & No & 1907 & Yes \\
\hline Isechuo & 1897 & $\mathrm{~N} / \mathrm{A}$ & 15360 & N/A & No & 1897 & Yes \\
\hline Nihon Boshoku & 1897 & $\mathrm{~N} / \mathrm{A}$ & 5712 & 1897 & No & 1905 & Yes \\
\hline Osaka Menshi & 1897 & N/A & 3246 & N/A & No & 1901 & No \\
\hline Saidaiji & 1897 & $\mathrm{~N} / \mathrm{A}$ & 6912 & $\mathrm{~N} / \mathrm{A}$ & No & 1898 & Yes \\
\hline Sanuki & 1897 & N/A & 10000 & 1897 & No & 1918 & Yes \\
\hline Awa & 1898 & Ishikawa & 5376 & $\mathrm{~N} / \mathrm{A}$ & No & 1907 & Yes \\
\hline Chugoku & 1898 & $\mathrm{~N} / \mathrm{A}$ & 4992 & 1899 & No & 1902 & Yes \\
\hline Fuji & 1898 & Taniguchi* & 28256 & 1898 & Yes & $\mathrm{N} / \mathrm{A}$ & $\mathrm{N} / \mathrm{A}$ \\
\hline Kashu & 1898 & Suzuki & 10368 & 1898 & No & 1898 & Yes \\
\hline Nakatsu & 1898 & N/A & 10368 & 1898 & No & 1902 & Yes \\
\hline Nihon Hosoito & 1898 & Hagino & 20096 & 1898 & No & 1903 & Yes \\
\hline Tokyo Gasu & 1898 & Hibiya & 20568 & 1898 & No & 1906 & Yes \\
\hline Yamato & 1898 & Takatsuji* & 11520 & 1898 & No & 1902 & Yes \\
\hline Chita & 1899 & Ishikawa & 13056 & 1899 & No & 1907 & Yes \\
\hline Kunijima & 1899 & Takatsuji* & 9184 & N/A & No & 1899 & Yes \\
\hline Shanghai & 1899 & Yoshida* & 19840 & 1899 & No & 1899 & Yes \\
\hline Yawatahama & 1899 & Suzuki & 5376 & N/A & No & 1903 & Yes \\
\hline
\end{tabular}

Note: N/A in the "Source of technological knowledge" means that engineers / technical advisors are unknown. N/A in "Year reached 10,000 spindles" means that the mill has never reached this threshold (at least as an independent firm). N/A in "Exit year" and "Exit by acquisition" means that the firm survived at least until 1920. * denotes college graduates. 
Table 4. Knowledge sources and penetration of cotton mixing, 1893

\begin{tabular}{l|l|l|l|l|l}
\multicolumn{2}{l}{} & \multicolumn{2}{l|}{$\begin{array}{l}\text { Fraction of Indian and U.S. cotton in } \\
\text { total }\end{array}$} & $\begin{array}{l}\text { Cotton mixing } \\
\text { index }\end{array}$ \\
\hline $\begin{array}{l}\text { Cource of knowledge-educated } \\
\text { engineer }\end{array}$ & Yes & 0.458 & $* * *$ & $3.278 * *$ \\
& No & 0.210 & & 2.500 \\
\hline & Yes & 0.170 & $* * *$ & $2.385 * *$ \\
Ishikawa & No & 0.410 & & 3.120 \\
\hline & Yes & 0.170 & & 2.385 \\
& No & & & \\
Ishikawa & $*$ & 0.285 & & 2.714 \\
\hline
\end{tabular}

Note: Last row excludes non-Ishikawa supervised firms whose source of knowledge came from college-educated engineers. ${ }^{* *}$, and $* *$ indicate that the corresponding difference is statistically significant at the 1 percent and 5 percent level, respectively, using double-sided $t$-test.

Table 5. Knowledge sources and capital to labor and

female to male operatives ratios, 1893

\begin{tabular}{l|l|r|r}
\multicolumn{2}{l|}{} & Capital to labor ratio & Female to male operatives ratio \\
\hline \multirow{4}{*}{ Source of knowledge } & Yes & $14.595 * * *$ & $3.816^{* * *}$ \\
College-educated engineer & No & $19.244 \quad 18.828$ \\
\hline \multirow{3}{*}{ Ishikawa } & Yes & $18.119 * *$ & $2.987^{* * *}$ \\
\hline \multirow{3}{*}{ Ishikawa } & No & 16.356 & 3.485 \\
\hline
\end{tabular}

Note: Last row excludes non-Ishikawa supervised firms whose source of knowledge came from college-educated engineers. ${ }^{* * *}$ indicates that the corresponding difference is statistically significant at the 1 percent level, using double-sided $t$-test.

Table 6. Knowledge sources and firm outcomes (1893-94)

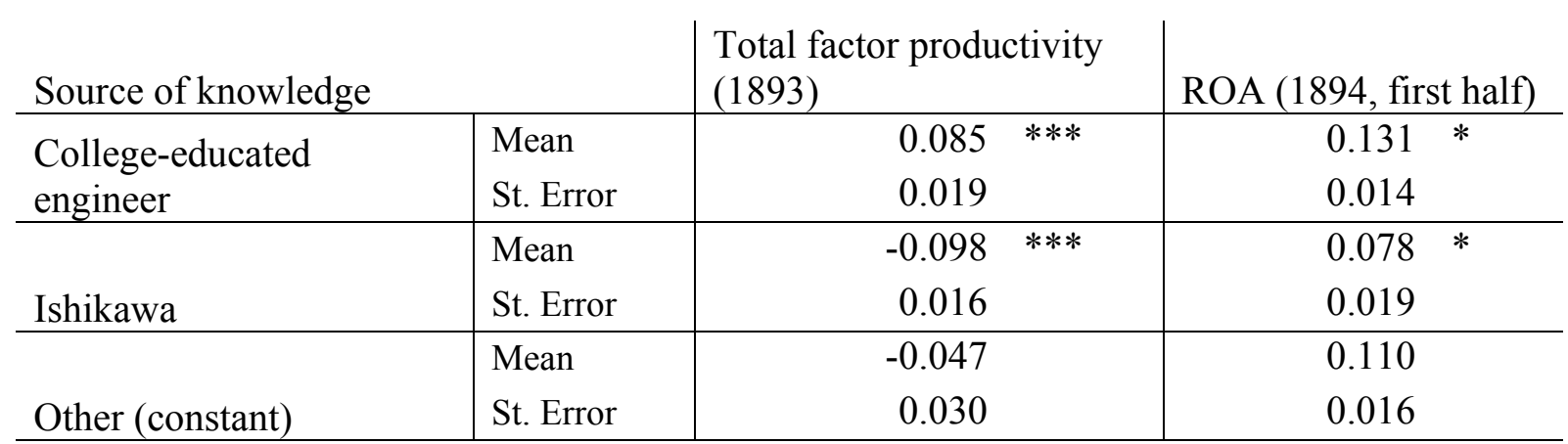

Note: Total factor productivity measure is the average residuals from estimating the production function as in (1) in the main text. ROA is return on assets, firms' reported profits divided over the value of total assets in the balance sheet. $* * *$, and * indicate that the corresponding difference is statistically significant at the 1 percent and 10 percent level, respectively, using double-sided $t$-test. 
Table 7. Knowledge sources, capital to labor ratio,

\section{female to male operatives ratio, and total factor productivity, 1898}

\begin{tabular}{l|l|r|r|r}
\multicolumn{2}{l|}{$\begin{array}{l}\text { Capital to labor } \\
\text { Source of knowledge }\end{array}$} & $\begin{array}{l}\text { Female to male } \\
\text { operatives ratio }\end{array}$ & $\begin{array}{l}\text { Total factor } \\
\text { productivity }\end{array}$ \\
\hline $\begin{array}{l}\text { College-educated } \\
\text { engineer }\end{array}$ & Mean & 15.772 & $3.829 * * *$ & -0.008 \\
& St. Error & 0.240 & 0.065 & 0.015 \\
\hline \multirow{3}{*}{ Ishikawa } & Mean & 14.852 & $3.423 * * *$ & -0.005 \\
& St. Error & 0.368 & 0.062 & 0.018 \\
\hline \multirow{3}{*}{ Other (constant) } & Mean & 15.907 & $3.660 * *$ & 0.016 \\
& St. Error & 0.396 & 0.065 & 0.018 \\
\hline
\end{tabular}

Note: Total factor productivity measure is the average residuals from estimating the production function as in (1) in the main text. $* * *$ and $* *$ indicate that the corresponding difference is statistically significant at the 1 and 5 percent level, respectively, using double-sided $t$-test.

Table 8. Knowledge sources and some outcomes (1898)

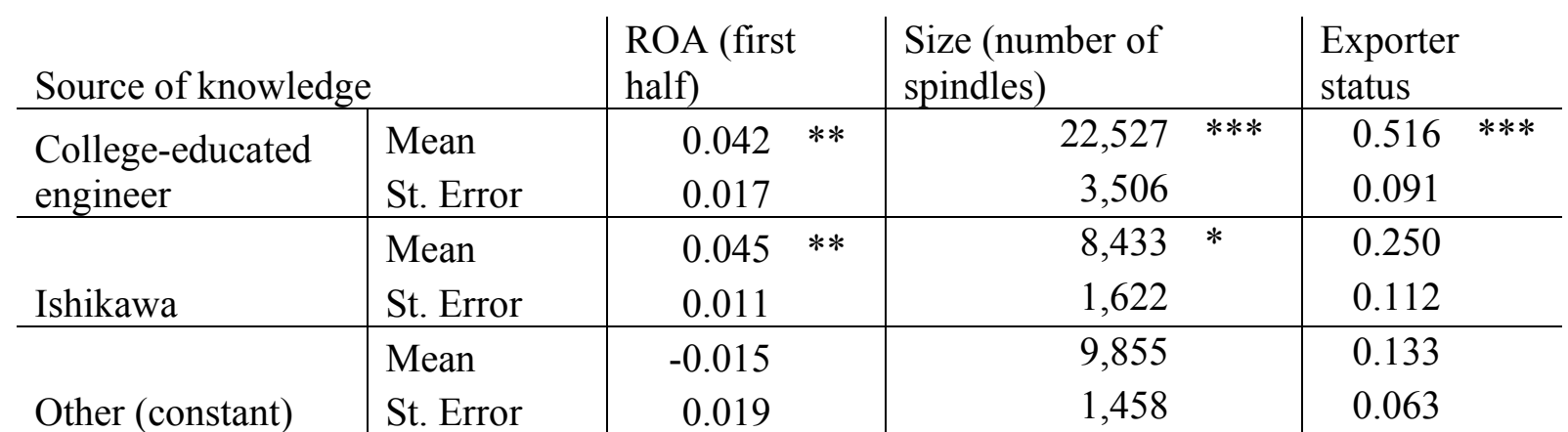

Note: ROA is return on assets, firms' reported profits divided over the value of total assets in the balance sheet. ***, $* *$, and * indicate that the corresponding difference is statistically significant at the 1 percent, 5 percent, and 10 percent level, respectively, using double-sided $t$-test. 


\title{
Endnotes
}

\begin{abstract}
${ }^{\mathrm{i}}$ Saxonhouse (1974) represents the first serious study of this story in English-language literature, although some of its aspects had been mentioned (often with misinterpretations, more on which below) by economic historians long before him (e.g., Smith, 1955; Landes, 1965). Among the Japanese historians, the two-volume treatise by Naosuke Takamura (1971) stands unsurpassed in many aspects even today by the breadth and depth of his coverage and careful attention to important details. Other contributions in the English-language literature include Saxonhouse and Wright (1984 and 2010), Ranis and Saxonhouse (1985), Ohyama, Braguinsky, and Murhpy (2004), Braguinsky and Rose (2009), Braguinsky, Ohyama, Okazaki, and Syverson (2015), and Braguinsky and Hounshell (2015a and b).

ii "[T] he astonishing ascendance of Osaka over Lancashire stands as the first completely successful instance of Asian assimilation of modern Western manufacturing techniques" (Saxonhouse, 1974:
\end{abstract} 150).

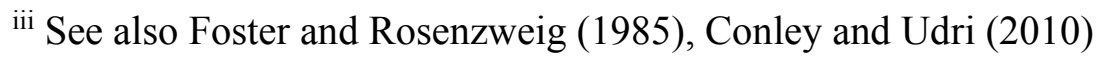

iv For example, Ransom Olds, the first great entrepreneur in the auto industry in Detroit, "probably trained more men of prime importance to the industry to-day than any other producer" (Doolittle, 1916, cited in Klepper, 2011: 145).

${ }^{\mathrm{v}}$ Cynics point out that this stance might have also been related to the anti-trust litigation brought up against AT\&T, the parent of Bell Labs at the time by the U.S. authorities. Recent investigative journalism has found that the situation may have changed in more recent years. See, e.g., Ames, M., "Revealed: Apple and Google's wage-fixing cartel involved dozens more companies, over one million employees," Pando Daily, Mar 22, 2014, http://bit.ly/1Ee1X0e. I am grateful to an anonymous referee for drawing my attention to this. That said, there were attempts to introduce a "no recruiting rule" among competing semiconductor firms in early years too, although in practice they did not seem to work (Tilton, 1971, p. 78). The same was true in the Japanese cotton spinning industry circa late $19^{\text {th }}$ century examined in the current paper. Examination of the actual effectiveness of the recent Silicon Valley wage-fixing cartel is a fascinating task for future research. ${ }^{v i}$ Lerner (2009) describes how SBIR (Small Business Innovation Research) program in the U.S. worked only in regions where high-tech venture funds were already operating. When the need to 
listen to private venture industry was ignored in the name of "diversity," "the program funded firms with inferior prospects.” (p. 130)

vii "Count" measures the thickness of the yarn, or how many yards of yarn are contained in each pound. The higher the count, the finer the thread. Producing yarn of higher counts (which is needed to produce higher-quality cloth) requires better-quality cotton input, more advanced technology, and more skilled labor, and it was a big challenge facing Japan's fledgling industry.

viii Saxonhouse was the first Western scholar to use these data in his dissertation (Saxonhouse, 1971). However, it appears that he (and many subsequent researchers) was under the erroneous impression that the first data became available only in July 1889 (when Boren's monthly bulletin was first published). In fact, as mentioned above, earlier data are also available in archives, through the government "Official Gazette" (Kampo). I thank Naosuke Takamura for pointing this out to me. The data used in this paper were coded by myself (for the years 1883-1893) and by Tetsuji Okazaki (for years 1894 and beyond). I thank Prof. Okazaki for generously sharing the data he has coded.

ix The mission also included 15 young men and boys, known as "Satsuma students," with orders to stay in England and learn sciences and engineering. Many of them later played key roles in modernizing Japan (Cobbing, 2000). Satsuma became one of the two main powers in the coalition that ushered in the new Meiji government

${ }^{\mathrm{x}}$ I use work-days and spindle-days as my measures of labor and capital inputs and not work-hours and spindle-hours because the data on hours in operation are not available for the year of 1885 . Using inputs adjusted also for hours per day the mill operated while dropping the 1885 observations leads to qualitatively very similar results.

${ }^{x i}$ It appears that Shibusawa arrived at the idea that Japan needed its own cotton spinning industry in order to limit the amount of money it spent on imports in 1879 , about the same time as the government embarked on its model mill-building policy (Geppo, 1921, September, pp. 31-32).

${ }^{x i i}$ Raising all the initially planned capital turned out to be difficult even for someone like Shibusawa; his initial plan had been to start the mill with 12,000 spindles but he was forced to start with 10,500 instead because of the capital constraint (Takamura, 1971, Vol. I, pp. 66-67). 